\title{
Final Technical Report \\ Power through Policy: "Best Practices" for Cost-Effective Distributed Wind
}

\author{
DOE Award Number: DE-EE0000503 \\ Project Period: 12/01/2009 through 11/30/2011 \\ Principal Investigator \\ Heather Rhoads-Weaver, eFormative Options \\ 206-567-5466, heather@eformativeoptions.com
}

\begin{abstract}
Authors
\end{abstract}
Matthew Gagne, eFormative Options, 503-703-6741, matt@eformativeoptions.com

Kurt Sahl, eFormative Options, 206-501-7126, kurt@eformativeoptions.com

Alice Orrell, Pacific Northwest National Laboratory, 509-372-4632, Alice.Orrell@pnnl.gov

Jennifer Banks, North Carolina Solar Center, 919-515-3799 jen_banks@ncsu.edu

\author{
Recipient organization \\ eFormative Options LLC \\ PO Box 47 \\ Vashon, Washington 98070 \\ Other project team members
}

Trudy Forsyth, National Renewable Energy Laboratory

Tony Jimenez, National Renewable Energy Laboratory

Amanda Vanega, North Carolina Solar Center

Laurel Varnado, North Carolina Solar Center

Maureen Quinlan, North Carolina Solar Center

Brian Miles, North Carolina Solar Center

Wade Fulghum, North Carolina Solar Center

Peter Asmus, eFormative Options

Alicia Healey, eFormative Options

Date of Report

$2 / 28 / 2012$ 


\section{Acknowledgements}

This report is based upon work supported by the U. S. Department of Energy under Award No. DE-EE0000503.

The authors would like to thank the many individuals and organizations that assisted us by providing data, thoughtful comments, and support. A special thanks to the U.S. DOE for providing funding for and supporting this work, specifically to Chris Fry, Breton Barker, Keith Bennett, Dwight Bailey, Jim Ahlgrimm, Michele DesAutels, Pam Brodie, and Melissa Luken. Thanks also to Bergey Windpower and Southwest Windpower for serving as in-kind cost-sharing partners and to all the other manufacturers who provided detailed information on their small wind turbines.

Invaluable information was provided by state energy program staff, including Rich Hasselman, Mick Sagrillo, Mark Mayhew, Betsey Kauffman, Lizzie Rubado, Erin Johnston, Darrin Kite, Aeron Teverbaugh, Matt Newberry, Larry Burton, Phil Lou, Jeff Goltz, James Jensen, Rich Stomberg, James Lee, Wayne Hartel, Gabriela Martin, Dick Fortier, Andrew Gohn, Joe Cohen, Scott Hunter, Peter McPhee, Andy Brydges, Tyler Leeds, John Campbell, Daniel Williams, Kathi Montgomery, Dave Ryan, John Hargrove, Corie Cheeseman, Sean Sever, Robert Nellis, Tara Lynch, Jeff Healion, Alma Rivera, Allison Capello, Preston Boone, Manny Anunike, Erika Myers, Gabrielle Stebbins, Lise Trudeau, Keith Kutz, Bob Leker, and others.

Numerous reviewers and advisers provided valuable guidance and feedback on draft materials. We greatly appreciate guidance and review by Jennifer Edwards, formerly with Lawrence Berkeley National Laboratory; Lisa Daniels, Windustry; Larry Sherwood, Small Wind Certification Council; Anne Margolis, Clean Energy States Alliance; Charles Newcomb, National Renewable Energy Laboratory; Steve Kalland, North Carolina Solar Center; Jennifer Williams, Artisan Electric; Andy Kruse, Southwest Windpower; Mike Bergey, Bergey Windpower; Robert Preus, Advanced Renewable Technology; Brett Pingree, Northern Power Systems; Jay Brandeis and Noah Bullock, Deerpath Energy/Southwest Windpower; Eric Lovely, Proven; Elena Sutherland, Gaia; Tal Mamo, Talco Electronics; Kevin Heaney and Marc Soulliare, Endurance; Joe Smith; and many others.

\section{Disclaimer}

Any findings, opinions, and conclusions or recommendations expressed in this report and accompanying software are those of the author(s) and do not necessarily reflect the views of the Department of Energy.

Neither the United States Government nor any agency thereof, nor eFormative Options LLC, nor the Pacific Northwest National Laboratory (PNNL), nor Battelle Memorial Institute, nor the National Renewable Energy Laboratory (NREL), nor the Alliance for Sustainable Energy LLC, nor the N.C. Solar Center (NCSC), nor N.C. State University (NCSU), nor any of their employees, makes any representation or warranty, express or implied, or assumes any legal liability or responsibility for the accuracy, completeness, reliability, suitability, or usefulness of any information, apparatus, product, or process disclosed, or represents that its use would not 
infringe privately owned rights. Reference herein to any specific commercial product, process, or service by trade name, trademark, manufacturer, or otherwise does not necessarily constitute or imply its endorsement, recommendation, or favoring by the United States Government or any agency thereof, or eFormative Options LLC, or Battelle Memorial Institute, or the Alliance for Sustainable Energy LLC, or North Carolina State University.

The information presented in this report, the Guidebook and on the Distributed Wind Policy Comparison Tool web site provides an unofficial overview of the impacts of financial incentives and other policies and is not directed to any specific transaction. While the project team has striven to make reasonable assumptions and provide the best information possible, the tool should not be used for making purchasing decisions, investment decisions, or tax decisions or when developing other binding agreements, and its results do not constitute professional tax advice or other professional financial guidance. The materials available at this web site are for informational purposes only and not for the purpose of providing legal advice. To ensure compliance with IRS Circular 230, please note (a) any discussion of federal tax issues in this presentation is not intended or written to be relied upon, and cannot be relied upon, by any person for the purpose of avoiding penalties that may be imposed on such persons under the U.S. Internal Revenue Code; and (b) as to specific information based on any transaction, participants should seek advice on their particular circumstances from an independent tax advisor. Please refer to the individual policies and incentive program web sites, web links provided via the Database of State Incentives for Renewables and Efficiency (DSIRE) website, to verify details of specific financial incentives or other policies. eFormative Options, PNNL, NREL, NCSC, and NCSU staff disclaim all liability of any kind arising out of your use or misuse of the information contained or referenced in this report, the Guidebook or on the Distributed Wind Policy Comparison Tool web pages.

Copyright 2012 eFormative Options LLC under DOE Award \# DE-EE0000503. Permission granted only for personal or educational use, or for use by or on behalf of the U.S. government. The unauthorized display, reproduction, sale, and/or distribution of all or portions of the content of the Distributed Wind Policy Comparison Tool and Guidebook are prohibited without prior written consent. 


\section{Table of Contents}

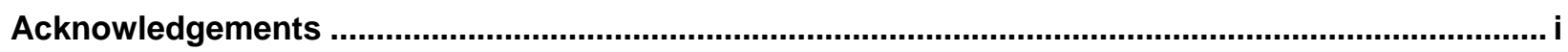

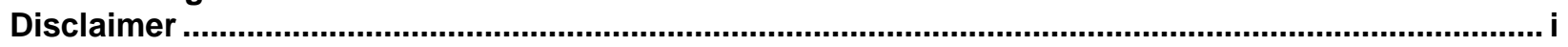

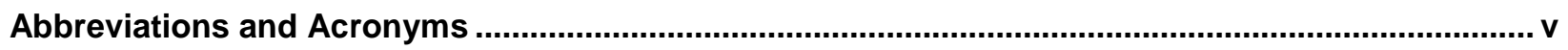

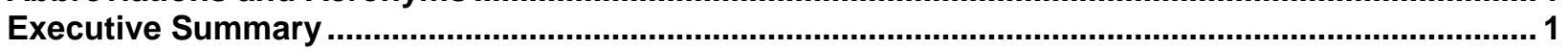

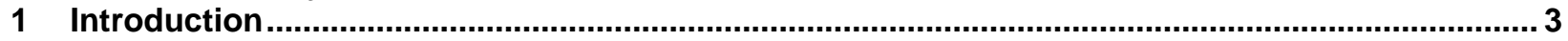

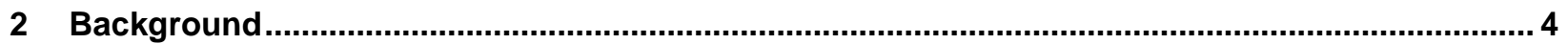

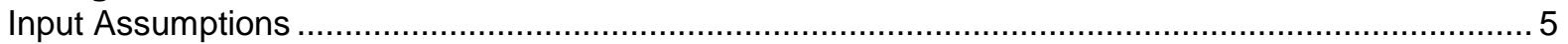

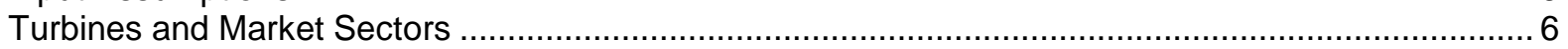

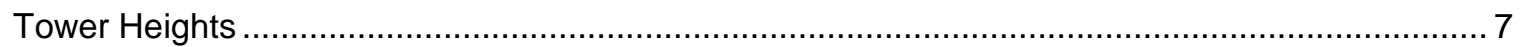

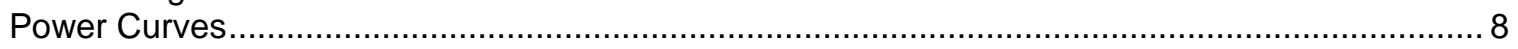

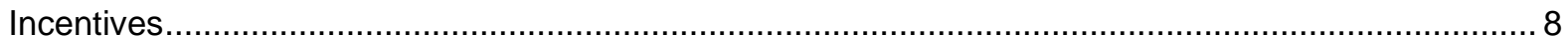

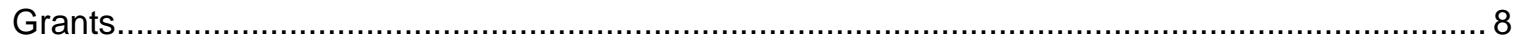

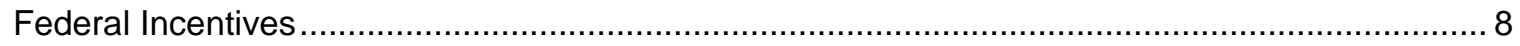

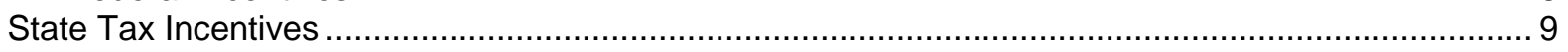

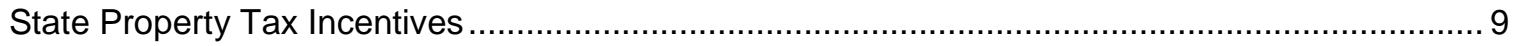

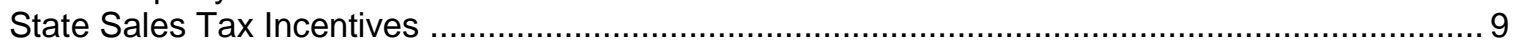

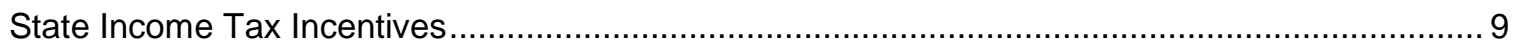

State Rebates and Performance-Based Incentives .............................................................. 9

Renewable Portfolio Standards and Renewable Energy Credits ............................................. 10

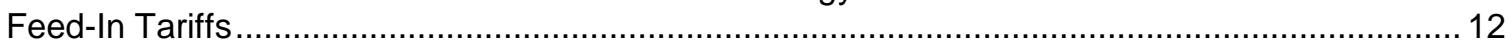

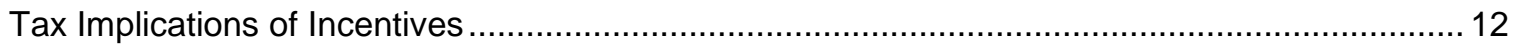

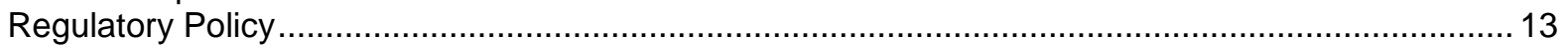

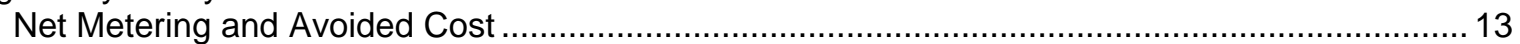

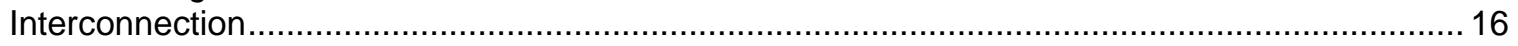

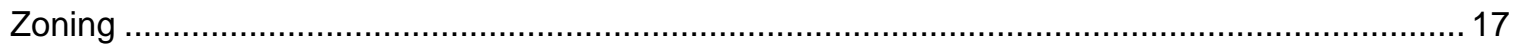

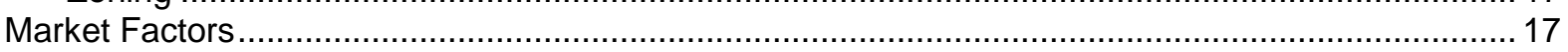

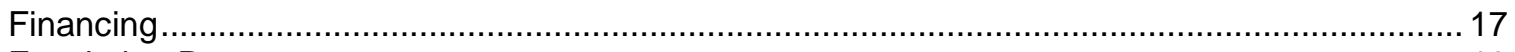

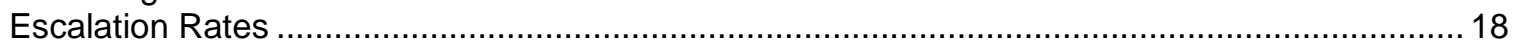

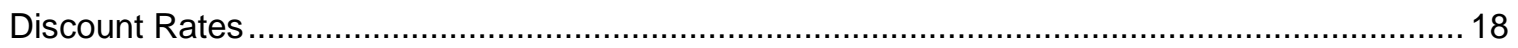

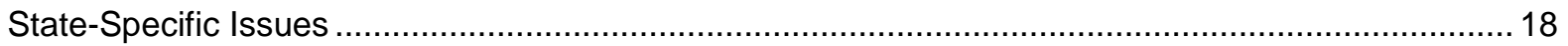

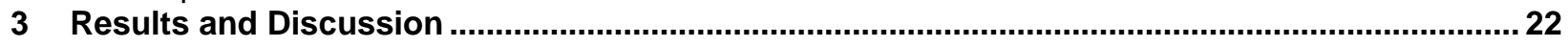

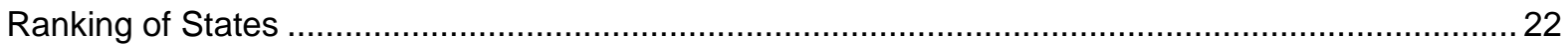

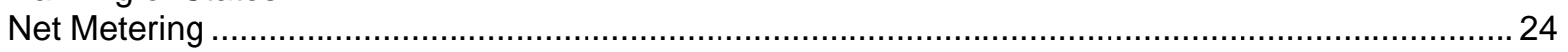

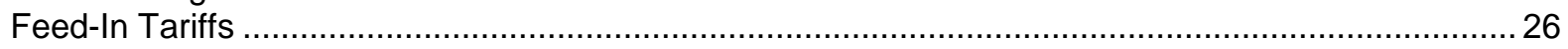

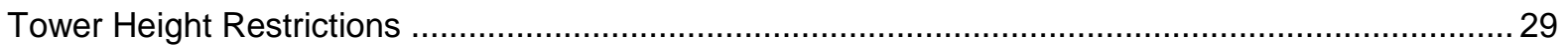

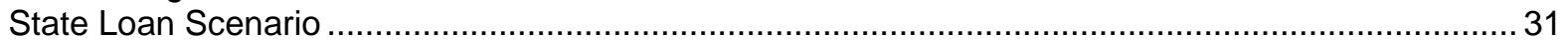

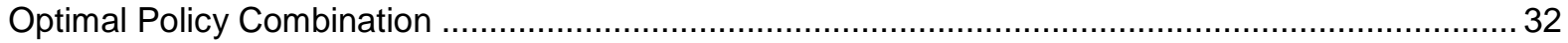

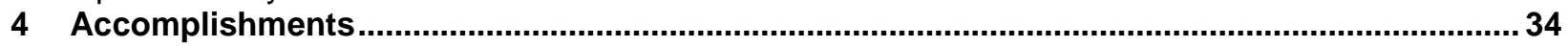

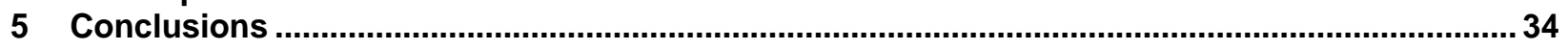

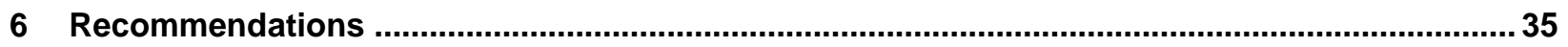

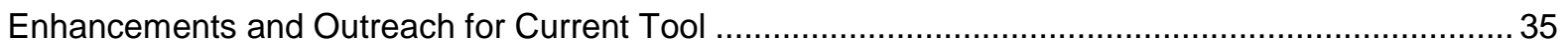

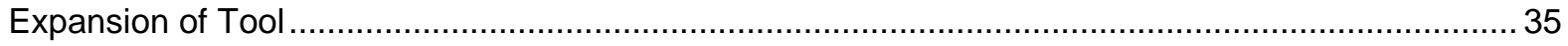

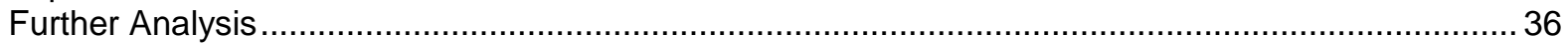

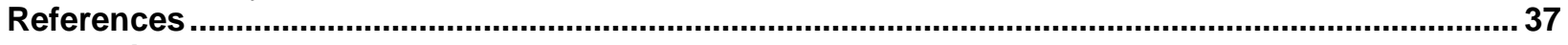

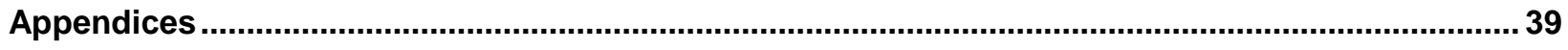




\section{List of Figures}

Figure 1 The Policy Tool's primary Inputs tab, showing default results. . .1

Figure 2 The Policy Tool's State tab, showing assumptions and default results ................................................

Figure 3 RPS policies with solar and distributed generation provisions........................................................11

Figure 4 Average COE results of base case scenarios (as of November 2011) ................................................23

Figure 5 Select IRR results of modeling FIT rates for the residential sector $(10-\mathrm{kW}$ turbine) $\ldots . . . . . . . . . . . . . . . . . . . . . .27$

Figure 6 Comparison of New York case study results with and without rebates and federal ITC....................29

\section{List of Tables}

Table 1 Net Metering Policies as of June 2011

Table 2 Project Economics for a 100-kW Commercial Turbine (with Net Metering Applied)...............................25

Table 3 States with Highest Electricity Prices .................................................................................................25

Table 4 Project Economics for Texas (with and without Net Metering) ............................................................26

Table 5 Select Results of Modeling Various FIT Rates for the Residential Sector (2.4-kW Turbine)..................28

Table 6 Project Economics for a Commercial-Sector 50-kW Turbine in New York..........................................30

Table 7 Wisconsin Focus on Energy Rebate Amounts for 20-kW Jacobs Turbine.............................................31

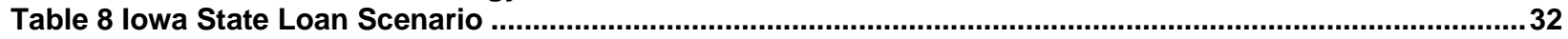

Table 9 Kansas Base Case Scenario for Commercial-Sector 100-kW Turbine vs. Alternate Inputs...................33

Table 10 Kansas Base Case Scenario for Commercial-Sector 100-kW Turbine vs. Optimized Policy

Combination.

\section{List of Appendices}

Appendix A Wind Turbines and Related Information Included in Policy Tool .............................39

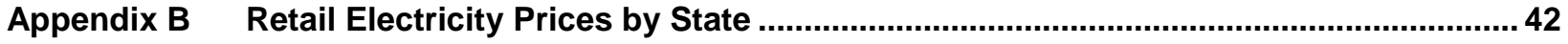

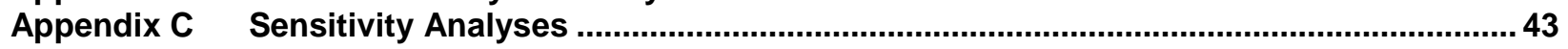

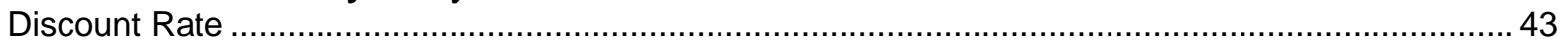

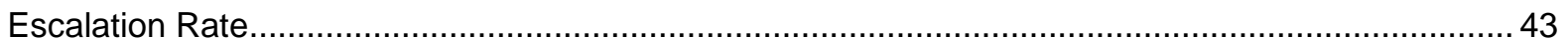

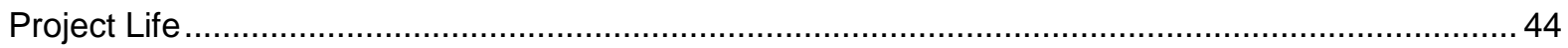

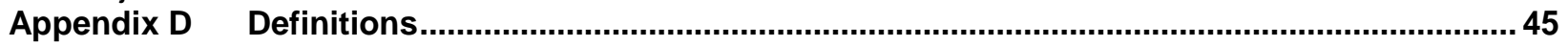




\section{Abbreviations and Acronyms}

Definitions are included in Appendix D.

CA-SGIP California's Self-Generation Incentive Program

COE cost of energy

DG distributed generation

DOE Department of Energy

DSIRE Database of State Incentives for Renewables and Efficiency

DWT distributed wind technology

EIA Energy Information Administration

ERP Emerging Renewables Program

FERC Federal Energy Regulatory Commission

FIT feed-in tariff

IOU investor-owned utility

IRR internal rate of return

ITC Investment Tax Credit

kW kilowatt

kWh kilowatt-hour

MACRS Modified Accelerated Cost Recovery System

$\mathrm{m} / \mathrm{s} \quad$ meters per second $(1 \mathrm{~m} / \mathrm{s}=2.24 \mathrm{mph})$

MWh megawatt-hour $(1 \mathrm{MWh}=1,000 \mathrm{kWh})$

NPV net present value

NREL National Renewable Energy Laboratory

O\&M operations and maintenance

PBI performance-based incentive

PTC Production Tax Credit

PURPA Public Utilities Regulatory Policy Act

REC renewable energy credit

REPI Renewable Energy Production Incentive

RPS renewable portfolio standard

SGIP Small Generator Interconnection Procedures

SWCC Small Wind Certification Council 


\section{Executive Summary}

Power through Policy: "Best Practices" for Cost-Effective Distributed Wind is a U.S. Department of Energy (DOE)-funded project to identify distributed wind technology policy best practices and to help policymakers, utilities, advocates, and consumers examine their effectiveness using a pro forma model. Incorporating a customized feed from the Database of State Incentives for Renewables and Efficiency (DSIRE), the Web-based Distributed Wind Policy Comparison Tool (Policy Tool) is designed to assist state, local, and utility officials in understanding the financial impacts of different policy options to help reduce the cost of distributed wind technologies.

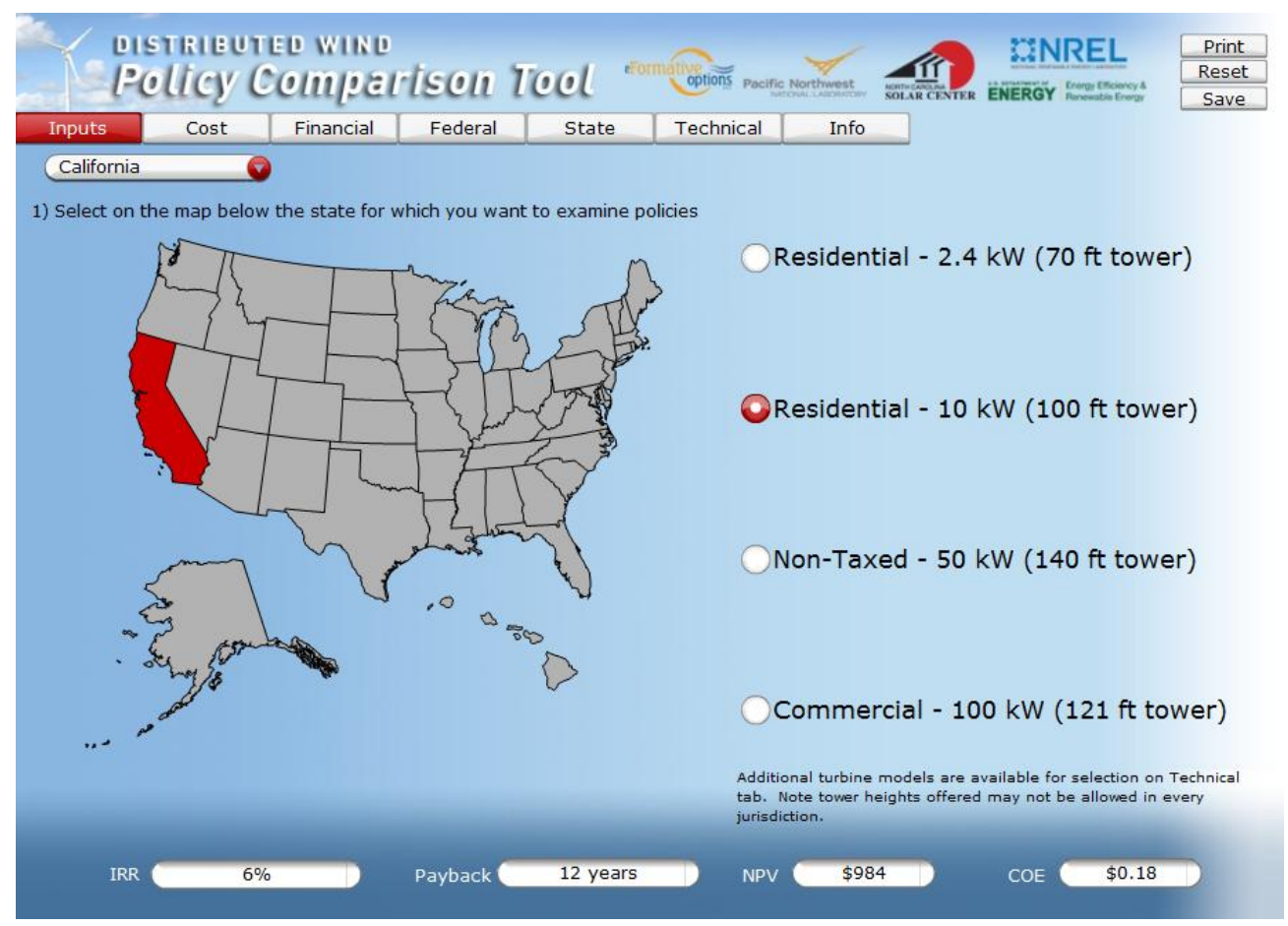

Figure 1 The Policy Tool's primary Inputs tab, showing default results

With only two initial user inputs required, the Policy Tool allows users to adjust and test a wide range of policy-related variables through a user-friendly dashboard interface with slider bars. The Policy Tool is populated with a variety of financial variables, including turbine costs, electricity rates, policies, and financial incentives; economic variables including discount and escalation rates; as well as technical variables that impact electricity production, such as turbine power curves and wind speed. The Policy Tool allows users to change many of the variables, including the policies, to gauge the expected impacts that various policy combinations could have on the cost of energy (COE), net present value (NPV), internal rate of return (IRR), and the simple payback of distributed wind projects ranging in size from 2.4 kilowatts $(\mathrm{kW})$ to $100 \mathrm{~kW}$.

The project conducted case studies to demonstrate how the Policy Tool can provide insights into "what if" scenarios and also allow the current status of incentives to be examined or defended when necessary. The ranking of distributed wind state policy and economic environments summarized in Section 4, based on the Policy Tool's default COE results, highlights favorable 
market opportunities for distributed wind growth as well as market conditions ripe for improvement. Best practices for distributed wind state policies are identified through an evaluation of their effect on improving the bottom line of project investments.

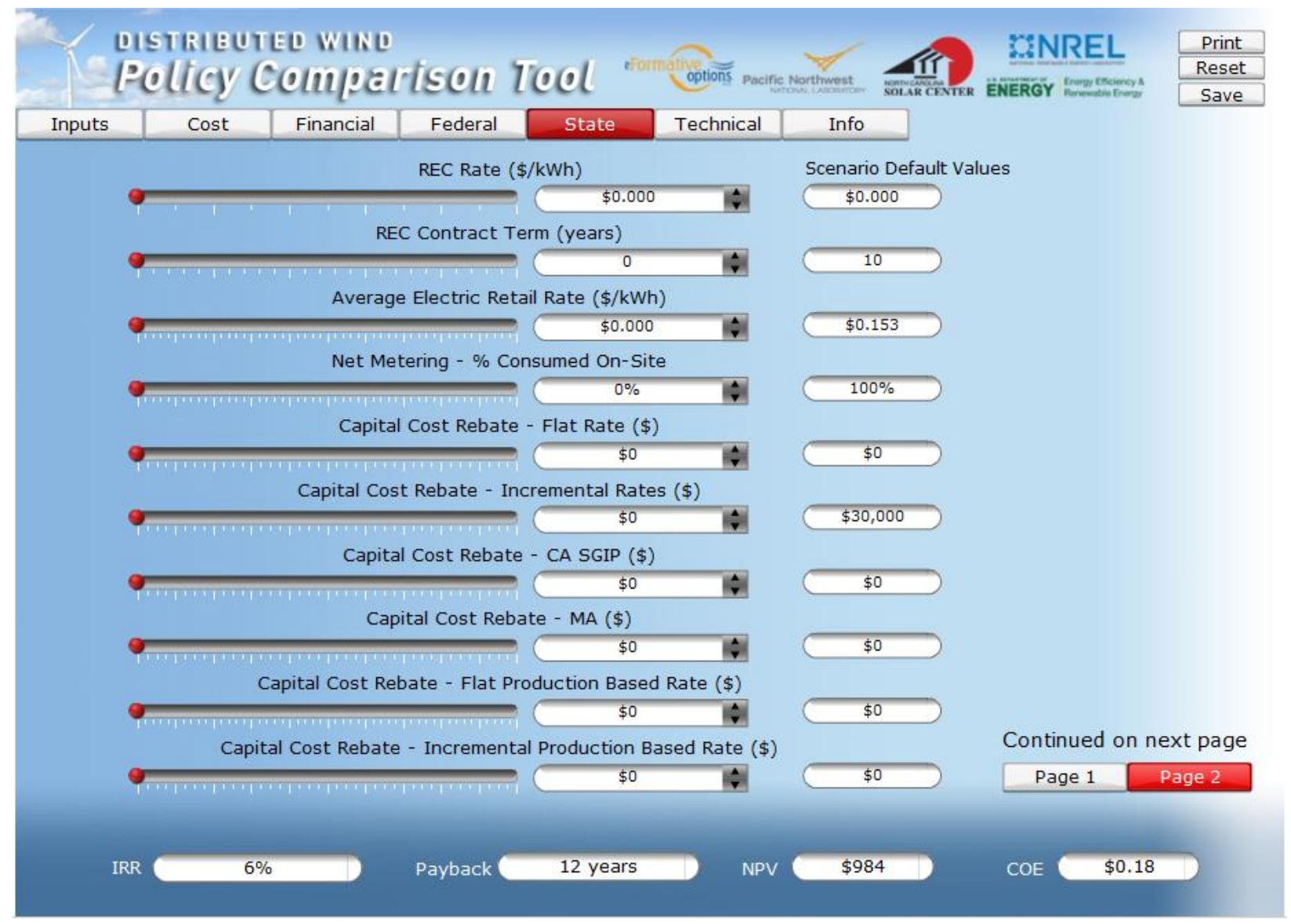

Figure 2 The Policy Tool's State tab, showing assumptions and default results

The Policy Tool can be used to evaluate the ways that a variety of federal and state policies and incentives impact the economics of distributed wind (and subsequently its expected market growth). It also allows policymakers to determine the impact of policy options, addressing market challenges identified in the U.S. DOE's " $20 \%$ Wind Energy by 2030 " report and helping to meet COE targets. 


\section{Introduction}

The widespread adoption of distributed wind technologies hinges on a holistic approach to policymaking. To encourage sustained growth, policymakers must consider the entire spectrum of on-site wind energy development issues, from zoning and permitting to financial feasibility indicators.

The Distributed Wind Policy Comparison Tool is a user-friendly, Web-based financial pro forma model designed to assist state and local policymakers in understanding the effects of policy options on reducing the costs of distributed wind. The Policy Tool and its accompanying guidebook are designed to help policymakers, utilities, advocates, and consumers advance the market for onsite wind generation across the nation through improved understanding of the policies that can impact the cost of distributed wind systems. The Policy Tool can aid advocates and program managers in defending successful incentives. With sustained, improved policies in place, wind turbines sited near the point of end use can quickly ramp up to meet local demand, allowing distributed wind technologies to play an important role in reaching DOE's $20 \%$ wind by 2030 scenario and in our energy future (see sidebar).

At the time eFormative Options was selected for award to develop the Power through Policy tool in 2009, the stated goal of the DOE Wind and Water Power Program's distributed wind energy activities was to expand the number of distributed wind turbines

\section{0\% Wind Energy by 2030: Increasing Wind Energy's Contribution to the U.S. Electricity Supply}

In July 2008, the U.S. Department of Energy published a report assessing the feasibility of wind supplying $20 \%$ of the United States' electricity by 2030 . The report was the culmination of 2 years of work and contributions from more than 50 organizations. The report and its conclusions continue to influence DOE wind program strategies. deployed in the U.S. market fivefold, from a baseline of 2,400 turbines installed in fiscal year 2007 to 12,000 turbines installed in 2015 . $^{2}$ Growth rates in the grid-connected market have remained strong in terms of installed capacity because the average installation size has increased substantially due to the availability of larger turbine sizes. However, 2010 has showed a decrease in the number of units installed. ${ }^{3}$ In 2011 the DOE Wind and Water Power Program established in a new goal associated with distributed wind energy because the number of units deployed annually is more strongly influenced by factors external to program activities. ${ }^{4}$

By determining how different variables impact the COE for distributed wind, the project team developed a pro forma model to identify "best practice" policy scenarios that support distributed

\footnotetext{
${ }^{1}$ U.S. Department of Energy, Energy Efficiency and Renewable Energy. 20\% Wind Energy by 2030: Increasing Wind Energy's Contribution to the U.S. Electricity Supply. July 2008. www.nrel.gov/docs/fy08osti/41869.pdf

${ }^{2}$ U.S. Department of Energy, Energy Efficiency and Renewable Energy, Wind and Water Program. Wind Energy Multiyear Program Plan for 2007-2012. August 2007. www1.eere.energy.gov/windandhydro/pdfs/40593.pdf

${ }^{3}$ American Wind Energy Association. AWEA Small Wind Turbine Global Market Study 2010. www.awea.org/learnabout/smallwind/loader.cfm?csModule=security/getfile\&PageID $=4420$

${ }^{4}$ New goal: Increase the number of small wind turbine designs certified to performance and safety standards from a 2010 baseline of 0 to 40 designs by 2020. Pages 23-24: www.cfo.doe.gov/budget/13budget/content/volume3.pdf
} 
wind in the most cost effective manner. As discussed in Section 4, state policies are evaluated based on their impact on improving the bottom line of distributed wind project investments. The Policy Tool and its accompanying guidebook are designed to allow efficient comparison of a wide variety of policy scenarios, allowing policymakers to easily see how their decisions impact consumer payback while accurately estimating the relative advantages of different options available in their policy toolboxes.

Designed for broad policy analysis, the Policy Tool is not a project-specific siting tool and is not capable of addressing site-specific variables. Section 2 reviews details on the data inputs in the underlying pro forma model.

Using initial inputs of state and project sector (residential, commercial, or non-taxed), the Policy Tool is populated with default values based on current market conditions, reasonable assumptions, and a data feed from DSIRE that can be updated as incentives and policies evolve. The Policy Tool provides users with the base case scenario, and users may adjust numerous default values through a dashboard interface. Enabling adjustable inputs allows the Policy Tool to stay current and flexible as state policies and market conditions continue to change.

The guidebook and this report assumes some prior knowledge of distributed wind incentives and does not attempt to explain every policy covered herein. For more background on these policies, including definitions and details of federal, state, and local policy, please refer to the DSIRE website.

The Policy Tool dashboard environment, while primarily aimed at providing users an easy way to understand the anticipated financial outcome, allows "what if" scenarios to be evaluated quickly. This feature will allow users to view and understand the impact of various factors, such as retail electric rates and renewable energy certificate (REC) prices, on specific project scenarios. Also, modeling different combinations of these variables (and adjusting the variables) allows users to see the effects that distinct policy options have on the $\mathrm{COE}$ and project economics and to identify optimal combinations of policy options that maximize the costeffectiveness of distributed wind turbines.

This project is one of 53 awarded funding provided in part through the American Recovery and Reinvestment Act to address market challenges identified in DOE's "20\% Wind Energy by 2030" report. ${ }^{6}$ Project team members include eFormative Options, Pacific Northwest National Laboratory, National Renewable Energy Laboratory, and the North Carolina Solar Center.

\section{Background}

Initially, the project team considered existing financial models and conducted a literature review of reports, discussions, and analyses related to distributed wind marketplace acceptance and policies supporting distributed wind technologies (included in the References section). Project team expertise was also tapped in developing the inputs for the model. To determine what incentives and policies influence the COE of distributed wind, the project team also conducted a

\footnotetext{
${ }^{5}$ The DSIRE glossary provides explanations of most policies covered in this report. See www.dsireusa.org/glossary

${ }^{6}$ The full report is available on the US DOE website: www1.eere.energy.gov/windandhydro/pdfs/41869.pdf
} 
questionnaire with three distinct groups: distributed wind turbine owner-operators; state incentive program managers, policymakers, and advocates; and distributed wind turbine manufacturers. The questionnaire provided insights into project-specific financial impacts of various policies and non-policy variables. The methods consisted of telephone interviews with 12 managers of state renewable energy incentive programs (or policy analysts, as appropriate), followed by three Web-based questionnaires completed by 15 incentive program managers, policymakers, and/or advocates; 19 wind turbine manufacturers; and 12 owners of small wind turbines.

The questionnaire results, while not conclusive or representative of any single group, served as a reference during the formation of the Policy Tool. The responses from state renewable energy incentive managers, policymakers, and advocates indicated that up-front cash incentives (including grants and rebates) and PBIs were perceived to be the most popular among consumers. The manufacturer responses rated the importance of policies on their market penetration. In aggregate, respondents identified the following policies as important in having potential to impact the market: rebate programs and federal tax credits; energy production incentives/feed-in tariffs (FITs); zoning/local wind ordinances; net metering; and loan programs. More than half of the small wind turbine owners indicated that federal tax credits and net metering were key considerations for purchasing a wind system.

\section{Input Assumptions}

The project team made numerous decisions and assumptions on inputs required to produce a robust interactive tool. Specifically, the project team considered the following variables for inclusion in the Policy Tool:

- Turbine and market sectors

○ Turbine selection

- Market sector selection

- Estimated turbine installation costs

$\circ$ Annual operating and maintenance costs

- Wind resource classes

- Tower heights

- Power curves

- Incentives

○ Grants

- Federal incentives

- State tax incentives

○ Property tax incentives

- Sales tax incentives

- Income tax Incentives

- State rebates, including PBIs

- RPS and RECs

- FITs

- Tax implications of incentives

- Regulatory policy

$\circ$ Net metering and avoided cost 
- Market factors

Interconnection
$\circ$ Zoning

○ Financing

- Escalation rates

- Discount rates

- Other state-specific issues.

The Policy Tool assumes, for example, that project owners may claim all of the available tax credits and deductions in the year such incentives are awarded. Also, the Policy Tool makes assumptions regarding what is considered taxable income and which expenses are tax-deductible. Each turbine/tower combination is assigned default permitting and interconnection costs based on team research and feedback from turbine manufacturers and installers.

It is important to understand these assumptions because they provide insight into the nuances and effects of policy provisions that may not be readily apparent when using the Policy Tool.

\section{Turbines and Market Sectors}

The Policy Tool was pre-populated with specific turbines at varying hub heights, which were selected based on their U.S. market share and progress toward Small Wind Certification Council (SWCC) certification (see sidebar on this page). ${ }^{7}$ Specifications are based on manufacturer documentation and standards.

The Policy Tool incorporates nine wind turbines. Five turbines are included with two tower heights, for a total of 14 turbine options. The market sectors included are residential, commercial, and non-taxed (such as nonprofits, local governments, and schools). On the Policy Tool's Inputs tab, four default turbine/tower combinations are provided to allow users to choose according to market sector.

The defaults provided for each sector are:

\section{Small Wind Certification Council}

The SWCC, an independent certification body, certifies small wind turbines that meet or exceed the requirements of the AWEA Small Wind Turbine Performance and Safety Standard.

This certification provides a common North American standard for reporting turbine energy and sound performance and helps small wind technology gain mainstream acceptance.

As of August 2011, manufacturers of 27 turbines are under contract with the SWCC and are working toward full certification and the consumer labeling process.

- Residential: 2.4-kW Skystream on 70-ft. guyed monopole

- Residential/Farm: 10-kW Bergey Excel on 100-ft. guyed lattice tower

- Non-Taxed: 50-kW Endurance E3120 on 140-ft. free-standing lattice tower

\footnotetext{
${ }^{7}$ www.smallwindcertification.org
} 
- Commercial: 100-kW Northwind 100 on 121-ft. free-standing monopole.

Users have the option of changing the turbine and tower height on the Technical tab in the Policy Tool. Detailed tower configurations, cost estimates including O\&M, and estimated annual production are provided in Appendix A. The turbine cost estimates were collected from turbine manufacturers and industry experts. The default assumed annual O\&M cost is $\$ 0.015 / \mathrm{kWh}$.

The Policy Tool limits wind class options to Low and Mid Class 2 (average $5.1-5.5 \mathrm{~m} / \mathrm{s}$ at 30$\mathrm{m}$ hub height ${ }^{8}$ ), Low and Mid Class 3 (average $5.8-6.1 \mathrm{~m} / \mathrm{s}$ at $30 \mathrm{~m}$ ), and Low Class 4 (average $6.4 \mathrm{~m} / \mathrm{s}$ at $30 \mathrm{~m}$ ). These ranges are provided to direct policy design for typical wind resources available for installations providing power for on-site use and tower height limitations. To guide users in gauging the impact of policies in slightly above-average (but not commercial-grade) wind regimes, the Policy Tool defaults to a target Class 2-3 wind resource for each state. To review economics, for example, seen by market clusters in better wind areas or by a larger portion of potential sites, users may adjust the wind resource selection on the Technical tab of the Policy Tool. Based on AWS Truepower's state wind resource ranking, ${ }^{9}$ Low Class 3 is the default assumption for Kansas, Montana, Nebraska, North Dakota, South Dakota, and Texas; Mid Class 2 is the default assumption for Colorado, Iowa, Oklahoma, Minnesota, New Mexico, and Wyoming; Low Class 2 is the default assumption for all other states.

Not all turbines within the Policy Tool are eligible for incentives and policies in every state, based on state-specific turbine certification and/or eligibility requirements. The Policy Tool does not take into account those eligibility requirements; rather, for comparison purposes, it assumes that all turbines are eligible for incentives with restrictions for size eligibility as the model allows. It should be noted that many states are beginning to require that turbines be certified by the SWCC in order to be eligible for incentives. For example, Energy Trust of Oregon and Wisconsin's Focus on Energy incentive programs are the first to require certification from the SWCC (starting January 1, 2012). The New York State Energy Research and Development Authority (NYSERDA) will accept SWCC certification for qualification for rebates (they also publish their own turbine lists), and the Massachusetts Clean Energy Center requires either SWCC certification or NYSERDA qualification. Programs in California, Colorado, Iowa, Maine, Maryland, Minnesota, Nevada, and Vermont have indicated their intention to follow suit. ${ }^{10}$

\section{Tower Heights}

Information on tower-height restrictions is not available at the state level because such restrictions are generally governed by local jurisdictions, such as counties and municipalities. To see the impact of a tower-height restriction, the Policy Tool allows users to pick from two tower heights for most turbines. The user can then compare the impact different tower heights have on the cost-effectiveness of distributed wind because a taller tower height typically results in higher energy production. In addition, a handful of state incentives are based on a turbine's energy production.

\footnotetext{
$830 \mathrm{~m}$ = approximately 98 feet; model assumes shear factor of 0.18 , typical for areas with low surface roughness (minimal impacts from terrain and obstructions); shear at actual sites varies from 0.1 - 0.6.

${ }^{9}$ www.windpoweringamerica.gov/wind_maps.asp\#potential

10 www.smallwindcertification.org/for-stakeholders/incentives
} 


\section{Power Curves}

Turbine power curves were supplied by manufacturers and tested and verified by the National Renewable Energy Laboratory (NREL) or third-party verified. When available, turbine manufacturers working toward SWCC certification supplied third-party verified power curves for the Policy Tool. The power curves assume standard conditions ( 0 feet elevation, sea level air density), reflecting how manufacturers' curves are typically presented. Each wind turbine's net energy production amount includes a $10 \%$ loss and is calculated with a 0.18 wind shear factor. ${ }^{11}$ The energy loss of $10 \%$ is based on a variety of factors, including the efficiency and availability of the collection system, and environmental factors such as ice and soiling of the blades. Wind shear is a mathematical factor used to estimate the wind speed at the hub height of a given turbine from a wind speed measured at lower height. See Appendix A for additional information.

\section{Incentives}

\section{Grants}

Given the competitive nature of grant programs and the fact that only a percentage of applicants will receive funding, the project team did not attempt to capture and monetize grants in the Policy Tool. The lone exception is the federal 1603 U.S. Treasury Grant, provided in lieu of the federal investment tax credit (ITC) for commercial projects, which is included. Nonetheless, both state and federal grant line item variables are included in the Policy Tool set to default values of $\$ 0$ so that users can apply grants to test their effect on project economics.

\section{Federal Incentives}

Federal incentives included in the Policy Tool include:

\section{- Residential:}

○ Residential Renewable Energy Tax Credit, as provided for in 26 USC $§ 25 D$.

\section{- Commercial:}

$\circ$ Business Energy ITC, as provided for in 26 USC $\S 48$

- Modified Accelerated Cost-Recovery System (MACRS) depreciation

○ U.S. Department of Treasury Payments for Specified Energy Property in Lieu of Tax Credits (also known as the Section 1603 Grant Program).

The project team did not include the Renewable Energy Production Incentive (REPI), which is designed for the non-taxed sector. Although this incentive is authorized by legislation (it was created by the federal Energy Policy Act of 1992), and annual appropriations have been authorized through 2026, funding is subject to the U.S. DOE budget process and has not been readily available or applicable since $2007 .^{12}$

The Policy Tool does not include the Federal Production Tax Credit (PTC) for several reasons. First, given the scope of the project (2.4-kW to $100-\mathrm{kW}$ turbines), the project team assumed that the commercial distributed wind projects would select the $30 \%$ ITC or the 1603 Cash Grant. A

\footnotetext{
${ }^{11} 0.18$ shear factor is specified in IEC 61400-2 ed. 3 and is typical for areas with low surface roughness (minimal impacts from terrain and obstructions); actual sites vary from $0.1-0.6$, and project advisers have suggested 0.3 may be more representative for distributed wind sites. A higher wind shear factor assumption would lower the estimated wind speeds at hub heights and thus annual energy production, particularly for shorter towers.

${ }^{12}$ Database of State Incentives for Renewables \& Efficiency. www.dsireusa.org/incentives/incentive.cfm?Incentive_Code=US33F\&re=1\&ee=1. Accessed 8/2010.
} 
Lawrence Berkeley National Laboratory and NREL economic analysis conducted comparing the PTC to the ITC concluded that in most cases, projects with installed costs of $\$ 1,500 / \mathrm{kW}$ or less would favor the PTC over the ITC, but those with installed costs greater than $\$ 2,500 / \mathrm{kW}$ would favor the ITC. Capacity factors also play a role. ${ }^{13}$ For the distributed wind turbine market, installed costs are typically higher than $\$ 2,500 / \mathrm{kW}$ due to lack of economies of scale. Capacity factors are lower because the turbines are installed on shorter towers and in slower wind speeds when compared to utility-scale developments. Furthermore, only projects that sell their electricity to a third party are eligible for the PTC. In many cases, selling to a third party would render projects ineligible for many possible distributed wind state incentives (such as rebates and net metering). This would negate the Policy Tool's purpose of comparing state-level policy options that best influence distributed wind's bottom line.

The Policy Tool assumes that only the commercial sector is allowed to claim MACRS depreciation since this incentive is not available to the non-taxed or residential sectors. Users are able to opt for MACRS, straight-line depreciation, and no depreciation to evaluate their effects.

The Policy Tool does not include "bonus" depreciation, which expired in 2009 but was temporarily reinstated in 2010 through the end of 2012 (at different rates for 2011 and 2012). The project depreciable amount is assumed to be $90 \%$ of the initial capital investment (the system cost) before state rebates are applied, less one-half of the federal ITC or 1603 Cash Grant. Because the Policy Tool assumes that state rebates are federally taxed, the depreciable amount and the basis for receiving the Federal ITC are not reduced by the rebate amounts.

\section{State Tax Incentives State Property Tax Incentives}

The Policy Tool does not attempt to capture and monetize property tax incentives. Site-specific property tax rates are determined locally, and the Policy Tool would need to input the property value of the site before and after installation in order to capture this type of incentive. This level of detail is outside the scope of this project.

\section{State Sales Tax Incentives}

State sales tax is included in the Policy Tool. Sales tax reductions or exemptions are monetized, where available, as part of the overall installed cost of the turbine. The Policy Tool uses data for state sales tax rates from the Federation of Tax Administrators. ${ }^{14}$

\section{State Income Tax Incentives}

State production tax credits (where applicable) are included, as are state income tax credits and deductions.

\section{State Rebates and Performance-Based Incentives}

The Policy Tool includes rebates that are mandated by state policy or programs. In reality, many "state rebates" are not available for all residents of a state because they are typically funded by a public benefits fund or RPS surcharge that is only paid by IOU ratepayers. As a result, many of

\footnotetext{
${ }^{13}$ Bolinger, M., R. Wiser (Lawrence Berkeley National Laboratory), C. Karlynn, and T. James (National Renewable Energy Laboratory). (2009). PTC, ITC, or Cash Grant? An Analysis of the Choice Facing Renewable Power Projects in the United States. http://eetd.lbl.gov/ea/emp/reports/lbnl-1642e.pdf

${ }^{14}$ Federation of Tax Administrators. (2010). www.taxadmin.org/fta/rate/tax_stru.html. Accessed 8/2010.
} 
the rebate programs are not available to customers of public utilities or electric cooperatives. This is an important caveat for the Policy Tool and for policymakers to note, especially when considering that electric cooperatives and public utility districts typically serve customers in rural areas with the best wind resources. Rebate programs in California, Delaware, Illinois, Massachusetts, Nevada, New Jersey, New York, Oregon, and Wisconsin are treated as "statewide" for simplicity in the model because these rebate programs are mandated by state policy and in many cases administered by state agencies (or entities selected by state agencies), but they are not available to every citizen of the state.

Rebates are typically based on a renewable energy system's capacity rating $(\$ / \mathrm{kW})$. States that base their rebates on rated capacity include California, Colorado, Delaware, District of Columbia, Maine, Maryland, Nevada, New Hampshire, Oregon, and Vermont. A few programs base rebate payments as a percentage of system cost, including Illinois and Minnesota.

Over the past few years, several state solar rebate programs have begun adopting more complex incentive structures to reward system performance rather than system capacity. ${ }^{15} \mathrm{~A}$ few wind rebate programs have done the same. True PBIs, also referred to as production incentives, provide cash payments based on the actual number of kilowatt-hours generated. Some states pay rebates that are based on expected performance rather than actual production, including New Jersey, New York, and Wisconsin (\$/kWh). Only one state (Arkansas) has based its rebate program payments on actual performance for 1 year. Washington also has a PBI. It is not a typical rebate program; the utilities pay the incentives and earn a tax credit equal to the cost of those payments. Maine also offers a choice of a REC multiplier or a PBI of $\$ .10 / \mathrm{kWh}$ for 20 years for eligible community-based renewable energy facilities. The Policy Tool assumes that Maine commercial and non-taxed entities would be eligible for this incentive and would choose the PBI (over the REC multiplier).

\section{Renewable Portfolio Standards and Renewable Energy Credits}

Traditionally, RPS policies have been most successful driving large, utility-scale wind development. ${ }^{16}$ Because of this, state policymakers have evolved policies in a way to support additional resource diversity, such as distributed renewable generation. The most common choice has been to establish set-asides for solar energy. The terms "set-aside" or "carve-out" refer to a provision within an RPS that requires utilities to use a specific renewable resource to account for a certain percentage of their retail electricity sales (or a certain amount of generating capacity) according to a set schedule. ${ }^{17}$

In some states with solar carve-outs (as shown in Figure 3), a robust market for S-RECs is emerging. Prices for S-RECs can reach hundreds of dollars per megawatt-hour. ${ }^{18}$ A few states have adopted "distributed generation" (DG) carve-outs that include distributed wind (Arizona,

\footnotetext{
${ }^{15}$ North Carolina Solar Center (2010). Solar Policy Guide. www.dsireusa.org/solar/solarpolicyguide

${ }^{16}$ Wiser, R., G. Barbose and E. Holt. (2010). Supporting Solar Power in Renewables Portfolio Standards: Experience from the United States. Lawrence Berkeley National Laboratory Report 3984E. http://eetd.lbl.gov/ea/emp/reports/lbnl-3984e.pdf

${ }^{17}$ Database of State Incentives for Renewables \& Efficiency. (2011). Glossary.www.dsireusa.org/glossary

${ }^{18}$ New Jersey has one of the longest experiences with its solar carve-out since 2007; weighted average S-REC prices for the first 4 months of 2011 surpassed \$600/MWh. www.njcleanenergy.com/renewable-energy/project-activityreports/srec-pricing/srec-pricing. Accessed 6/22/2011.
} 
Colorado, New Mexico, and New York), but none have developed an RPS provision specific to distributed wind. ${ }^{19}$ And even in states with DG carve-outs, utilities are not required to support distributed wind to meet the targets. As a result, a "distributed wind REC market" does not exist separately from the overall REC market.

The Policy Tool does not take into account credit multipliers within RPS policies as there is little evidence that they have an impact for distributed wind ${ }^{20}$ Furthermore, there are no distributed wind credit multipliers. ${ }^{21}$

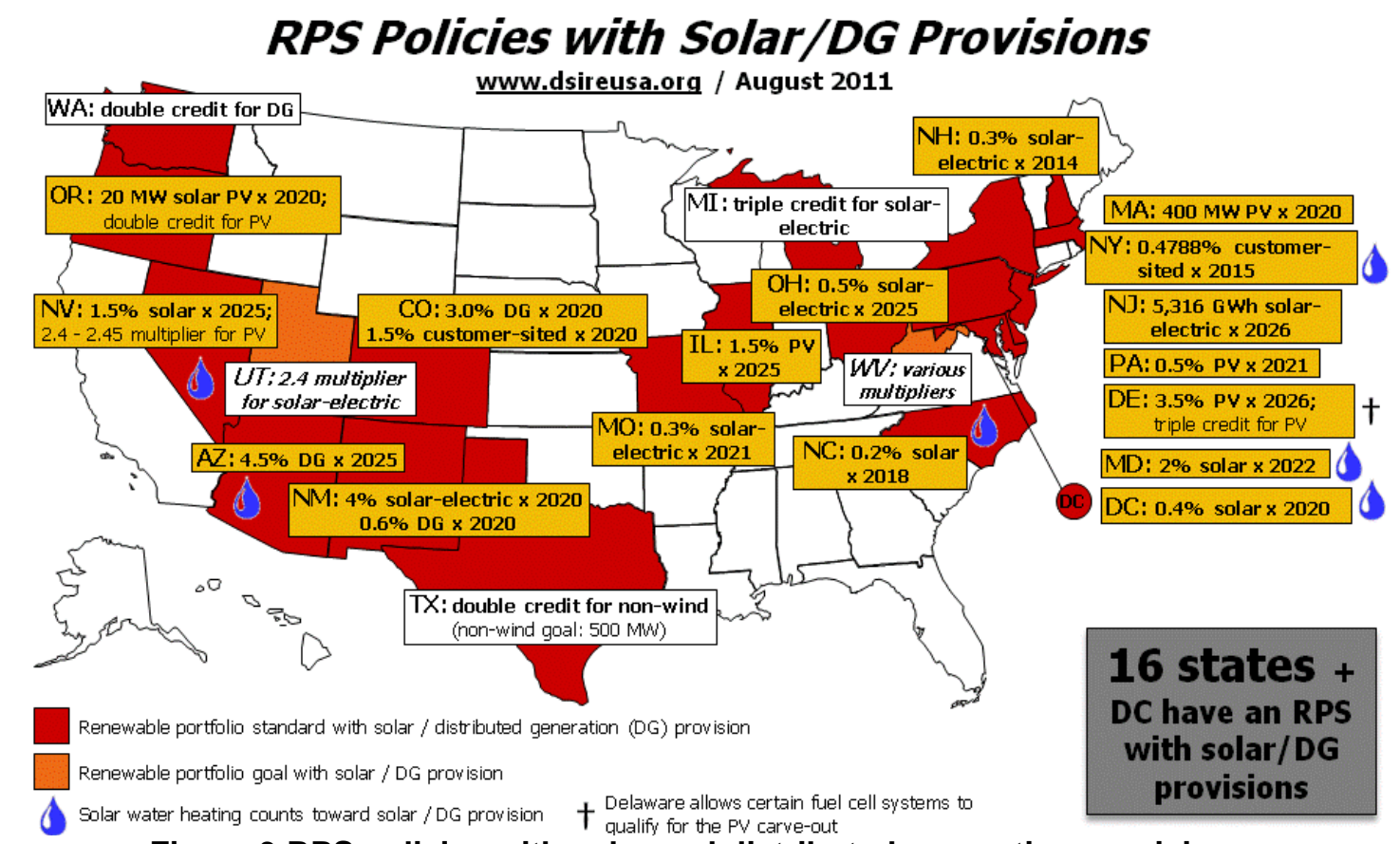

Figure 3 RPS policies with solar and distributed generation provisions

The average state REC prices included in the Policy Tool reflect whether utilities have to meet obligations through state RPS compliance, as credits in compliance markets carry a higher value than voluntary market credits. ${ }^{22}$ There is no separate input in the Policy Tool for "RPS" because the impact of a state's RPS is assumed to be captured in the REC market value. Users can change the default REC value for a state to simulate a distributed wind carve-out scenario.

\footnotetext{
${ }^{19}$ NYSERDA's small wind rebate program is funded by the RPS to meet the customer-sited tier requirements of the state's RPS. NYSERDA keeps the RECs from rebate-funded small wind turbines for the first 3 years, and the customer owns them after that. However, the value is negligible on the voluntary market, and REC trading is not currently an option in New York because the RPS is centrally managed by NYSERDA.

${ }^{20}$ Wiser, R., G. Barbose and E. Holt. (2010). Supporting Solar Power in Renewables Portfolio Standards:

Experience from the United States. http://eetd.lbl.gov/ea/emp/reports/lbnl-3984e.pdf

${ }^{21}$ Database of State Incentives for Renewables \& Efficiency (2011). RPS Policies with Solar/DG Provisions. www.dsireusa.org/documents/summarymaps/Solar_DG_RPS_map.pptx

${ }^{22}$ Ibid.
} 
The project team also assumed that RECs are available only to the commercial and non-taxed sectors. For the residential sector, the default value for RECs is zero. Where state-specific rates were not available, the project team used the National Green-E Certificate Wind REC value, with all rates from REC market broker quotes as of July 2010.

\section{Feed-In Tariffs}

The Policy Tool includes a FIT option as a user input. Only two states, Hawaii and Vermont, have enacted FIT policies applicable to distributed wind. When using the Policy Tool for Hawaii, the user must choose either net metering or the FIT. In Vermont, the default for the FIT is zero because it is assumed that the state's rebate and net metering are more readily available to the turbines included in the Power through Policy project scope. ${ }^{23}$ Despite the limited experience with FITs for distributed wind in the United States to date, including the FIT as a policy option allows users to evaluate the impact a potential FIT would have on distributed wind project economics. Furthermore, it will ensure that the Policy Tool is relevant in the future if FITs become more common. FITs are a type of PBI, although FITs pay higher rates, do not have payment caps, and have longer contract terms (5 to 20 years) than the PBIs previously mentioned. The term FIT also implies a wholesale transaction that carries tax and other implications. 24

\section{Tax Implications of Incentives}

Many of the incentives incorporated into the Policy Tool carry tax implications that the project team had to account for in the design process through the following assumptions:

- Capital cost rebates reduce the capital cost of the project and are considered taxable income for federal tax purposes. The system cost basis is not reduced for the ITC and depreciation calculations.

- O\&M costs are not expensed on taxes for the residential sector in the Policy Tool's underlying pro forma model.

- The Policy Tool assumes that project owners may claim all of the available tax credits and deductions in the year that such incentives are awarded. In other words, the project owner's tax liability is always greater than tax incentives.

- When an incentive such as a state tax credit or deduction cannot exceed a certain percentage of the wind system's overall value, the value used for the incentive calculation is based on the system cost after rebates but before sales tax, interconnection costs, and permitting costs.

- Income from REC sales, FIT payments, and PBI payments are considered taxable income.

- All loans (home mortgage, business, and state) are assumed to have tax-deductible interest.

\footnotetext{
${ }^{23}$ According to the Vermont SPEED Facilitator web site, only one 100-kW wind project has been accepted into the program and one is on the wait list. http://vermontspeed.com/standard-offer-program/ Accessed 6/22/2011.

${ }^{24}$ For more information on FIT policy design options, see Couture, T.D.; Cory, K.; Kreycik, C.; Williams, E. “Policymaker's Guide to Feed-in Tariff Policy Design.” July 2010. NREL Technical Report TP-6A2-44849. www.nrel.gov/docs/fy10osti/44849.pdf
} 
- An average default federal tax rate is assumed for the residential sector $(19.71 \%)^{25}$ and the commercial sector $(31.88 \%){ }^{26}$

- An average state income tax rate is also assumed (when applicable) for the residential sector and the commercial sector. It should be noted that a handful of states do not have personal income tax (Alaska, Florida, New Jersey, Nevada, South Dakota, Tennessee, Texas, Washington, and Wyoming) or corporate income tax (Nevada, Ohio, South Dakota, Washington, and Wyoming). ${ }^{27}$ The Policy Tool uses data on state income tax rates from the Federation of Tax Administrators. However, some states (for example, Washington) have unique business taxes that are not included in the default assumptions. Users can adjust taxes and other variables as desired.

\section{Regulatory Policy}

\section{Net Metering and Avoided Cost}

The Policy Tool considers net metering policies to be "statewide" only if net metering is consistently offered by the rural electric cooperatives ("co-ops"), municipal and public utilities, and IOUs operating in that state. Table 1 provides the details on the status of each state's net metering policy as of June 2011.

The value of net metering is assumed to be the full state average retail rate in states with statewide net metering. However, some utilities charge residential customers increasing block rates, such as Southern California Edison's $\$ 0.16-\$ 0.38 / \mathrm{kWh}$, in which wind generation saves the most expensive electricity first. For states without net metering, or for which net metering policies only apply to certain utilities, the Policy Tool assumes that the electricity generated would only receive the avoided-cost rate from the utility (estimated at $41 \%$ of retail value). ${ }^{28}$

For states with a statewide net metering policy, all wind energy generation consumed on-site is assumed to replace electricity that would have otherwise been purchased at the retail rate. Therefore (electric retail rate $\mathrm{x} \mathrm{kWh}$ consumed on-site) + (avoided cost rate $\mathrm{x} \mathrm{kWh}$ not consumed on-site $)=$ utility bill savings. The average retail electricity rates for each state are from the Energy Information Administration (EIA) website (2008 data), shown in Appendix B. ${ }^{29}$ The non-taxed sector rate is assumed to be the same as the commercial sector rate.

The Policy Tool's net metering default setting assumes that $100 \%$ of generation is consumed onsite. Users are able to adjust a "percent consumed on-site" input value to see what effect it has on the $\mathrm{COE}$ if the net-metered system is oversized. This allows annual net excess generation (the percent not consumed on-site by the end of a 12-month period) to be valued at the assumed avoided cost rate.

\footnotetext{
${ }^{25} 2008$ average federal income tax rate: www.irs.gov/taxstats/indtaxstats/article/0,,id=133521,00.html. Accessed $8 / 2010$.

${ }^{26}$ www.smbiz.com/sbrl001.html. Accessed 8/2010.

${ }^{27}$ Federation of Tax Administrators. (2010). www.taxadmin.org/fta/rate/tax_stru.html. Accessed 8/2010.

${ }^{28}$ The project team determined $41 \%$ to be a best estimate based on an average of available avoided cost rates found in each U.S. region.

${ }^{29}$ www.eia.doe.gov/cneaf/electricity/epa/epa_sprdshts.html
} 
Table 1 Net Metering Policies as of June 2011

\begin{tabular}{|c|c|c|c|c|c|}
\hline State & $\begin{array}{l}\text { Applicable } \\
\text { to IOUs? }\end{array}$ & $\begin{array}{c}\text { Applicable to } \\
\text { Co-ops? }\end{array}$ & $\begin{array}{c}\text { Applicable to } \\
\text { Public } \\
\text { Utilities? }^{31} \\
\end{array}$ & $\begin{array}{c}\text { Applicable system capacity } \\
\text { limits }^{32}\end{array}$ & $\begin{array}{l}\text { State- } \\
\text { Wide? }\end{array}$ \\
\hline Alaska & Some & $\mathrm{N}$ & $\mathrm{N}$ & $\mathrm{n} / \mathrm{a}$ & $\mathrm{N}$ \\
\hline Alabama & $\mathrm{N}$ & $\mathrm{N}$ & $\mathrm{N}$ & $\mathrm{n} / \mathrm{a}$ & $\mathrm{N}$ \\
\hline Arkansas & $\mathrm{Y}$ & $\mathrm{Y}$ & $\mathrm{N}$ & $\mathrm{n} / \mathrm{a}$ & $\mathrm{N}$ \\
\hline Arizona & $\mathrm{Y}$ & $\mathrm{Y}$ & $\mathrm{N}$ & $\mathrm{n} / \mathrm{a}$ & $\mathrm{N}$ \\
\hline California & $\mathrm{Y}$ & $\mathrm{Y}$ & $\begin{array}{c}\text { All but } \\
\text { LADWP, but } \\
\text { it has adopted } \\
\text { net metering }\end{array}$ & $\mathrm{n} / \mathrm{a}$ & $\mathrm{Y}$ \\
\hline Colorado & Y & Y & Some & $\begin{array}{c}\text { Municipals and co-ops: } 25 \\
\text { kW for non-residential; } 10 \\
\text { kW for residential; IOUs: } \\
\text { 120\% of customer's average } \\
\text { annual consumption }\end{array}$ & $\mathrm{N}$ \\
\hline Connecticut & $\mathrm{Y}$ & $\mathrm{n} / \mathrm{a}$ & $\mathrm{N}$ & $\mathrm{n} / \mathrm{a}$ & $\mathrm{N}$ \\
\hline District of Columbia & $\mathrm{Y}$ & $\mathrm{n} / \mathrm{a}$ & $\mathrm{n} / \mathrm{a}$ & $\mathrm{n} / \mathrm{a}$ & $\mathrm{Y}$ \\
\hline Delaware & $\mathrm{Y}$ & $\mathrm{Y}$ & $\mathrm{Y}$ & $\mathrm{n} / \mathrm{a}$ & $\mathrm{Y}$ \\
\hline Florida & $\mathrm{Y}$ & $\mathrm{N}$ & $\mathrm{N}$ & $\mathrm{n} / \mathrm{a}$ & $\mathrm{N}$ \\
\hline Georgia & $\mathrm{Y}$ & $\mathrm{Y}$ & $\mathrm{Y}$ & $\mathrm{n} / \mathrm{a}$ & $\mathrm{Y}$ \\
\hline Hawaii & Y & $\mathrm{Y}$ & $\mathrm{n} / \mathrm{a}$ & $\begin{array}{c}50 \mathrm{~kW} \text { for Kauai Island } \\
\text { Utility Cooperative }\end{array}$ & $\mathrm{Y}$ \\
\hline Iowa & $\mathrm{Y}$ & $\mathrm{N}$ & $\mathrm{N}$ & $\mathrm{n} / \mathrm{a}$ & $\mathrm{N}$ \\
\hline Idaho & $\begin{array}{l}\text { Varies by } \\
\text { utility }\end{array}$ & $\mathrm{N}$ & $\mathrm{N}$ & Varies by utility & $\mathrm{N}$ \\
\hline Illinois & $\mathrm{Y}$ & $\mathrm{N}$ & $\mathrm{N}$ & $40 \mathrm{~kW}$ & $\mathrm{~N}$ \\
\hline Indiana & $\mathrm{Y}$ & $\mathrm{N}$ & $\mathrm{N}$ & $\mathrm{n} / \mathrm{a}$ & $\mathrm{N}$ \\
\hline Kansas & $\mathrm{Y}$ & $\mathrm{N}$ & $\mathrm{N}$ & $\mathrm{n} / \mathrm{a}$ & $\mathrm{N}$ \\
\hline Kentucky & $\mathrm{Y}$ & $\mathrm{Y}$ & $\mathrm{N}$ & $30 \mathrm{~kW}$ & $\mathrm{~N}$ \\
\hline Louisiana & $\mathrm{Y}$ & $\mathrm{Y}$ & $\mathrm{Y}$ & $\mathrm{n} / \mathrm{a}$ & $\mathrm{Y}$ \\
\hline Massachusetts & $\mathrm{Y}$ & $\mathrm{N}$ & $\mathrm{n} / \mathrm{a}$ & $\mathrm{n} / \mathrm{a}$ & $\mathrm{N}$ \\
\hline Maryland & $\mathrm{Y}$ & $\mathrm{Y}$ & $\mathrm{Y}$ & $\mathrm{n} / \mathrm{a}$ & $\mathrm{Y}$ \\
\hline Maine & $\mathrm{Y}$ & $\mathrm{Y}$ & $\mathrm{Y}$ & $\mathrm{n} / \mathrm{a}$ & $\mathrm{Y}$ \\
\hline Michigan & $\mathrm{Y}$ & Some & $\mathrm{N}$ & $\mathrm{n} / \mathrm{a}$ & $\mathrm{N}$ \\
\hline Minnesota & $\mathrm{Y}$ & $\mathrm{Y}$ & $\mathrm{Y}$ & $40 \mathrm{~kW}$ & $\mathrm{Y}$ \\
\hline Mississippi & $\mathrm{N}$ & $\mathrm{N}$ & $\mathrm{N}$ & $\mathrm{n} / \mathrm{a}$ & $\mathrm{N}$ \\
\hline Montana & Y & Majority & $\mathrm{n} / \mathrm{a}$ & $\begin{array}{c}50 \mathrm{~kW} \text { for IOUs, } 10 \mathrm{~kW} \text { for } \\
\text { co-ops }\end{array}$ & Y \\
\hline North Carolina & $\mathrm{Y}$ & $\mathrm{N}$ & $\mathrm{N}$ & $\mathrm{n} / \mathrm{a}$ & $\mathrm{N}$ \\
\hline
\end{tabular}

${ }^{30}$ Some states do not have rural electric cooperatives. EIA: Table 10. Class of Ownership, Number of Consumers, Sales, Revenue, and Average Retail Price by State and Utility: All Sectors, 2009.

www.eia.gov/cneaf/electricity/esr/table10.html. Accessed 6/23/2011.

${ }^{31}$ Some states do not have publicly owned (municipal) utilities or Public Utility Districts. EIA: Table 10. Class of Ownership, Number of Consumers, Sales, Revenue, and Average Retail Price by State and Utility: All Sectors, 2009. www.eia.gov/cneaf/electricity/esr/table10.html. Accessed 6/23/2011.

${ }^{32}$ The Policy Tool does not take into account states' net metering system size limits shown, only whether the policy is considered to be statewide. For example, Hawaii, Minnesota, Montana, Nebraska, Oregon, and West Virginia have system size limits that are below $100 \mathrm{~kW}$ for net metering, at least for certain utility types. 
Table 1 (continued) Net Metering Policies as of June 2011

\begin{tabular}{|c|c|c|c|c|c|}
\hline State & $\begin{array}{l}\text { Applicable } \\
\text { to IOUs? }\end{array}$ & $\begin{array}{c}\text { Applicable to } \\
\text { Co-ops? }\end{array}$ & $\begin{array}{c}\text { Applicable to } \\
\text { Public } \\
\text { Utilities? }^{34}\end{array}$ & $\begin{array}{l}\text { Applicable system } \\
\text { capacity limits? }\end{array}$ & State-Wide? \\
\hline North Dakota & $\mathrm{Y}$ & $\mathrm{N}$ & $\mathrm{N}$ & $\mathrm{n} / \mathrm{a}$ & $\mathrm{N}$ \\
\hline Nebraska & $\mathrm{Y}$ & $\mathrm{Y}$ & $\mathrm{Y}$ & $25 \mathrm{~kW}$ & $\mathrm{Y}$ \\
\hline New Hampshire & $\mathrm{Y}$ & $\mathrm{Y}$ & $\mathrm{Y}$ & $\mathrm{n} / \mathrm{a}$ & $\mathrm{Y}$ \\
\hline New Jersey & $\mathrm{Y}$ & Some & Some & $\mathrm{n} / \mathrm{a}$ & $\mathrm{N}$ \\
\hline New Mexico & $\mathrm{Y}$ & $\mathrm{Y}$ & $\mathrm{N}$ & $\mathrm{n} / \mathrm{a}$ & $\mathrm{N}$ \\
\hline Nevada & $\mathrm{Y}$ & $\mathrm{N}$ & $\mathrm{N}$ & $\mathrm{n} / \mathrm{a}$ & $\mathrm{N}$ \\
\hline New York & $\mathrm{Y}$ & $\mathrm{N}$ & LIPA & $\mathrm{n} / \mathrm{a}$ & $\mathrm{N}$ \\
\hline Ohio & $\mathrm{Y}$ & $\mathrm{N}$ & $\mathrm{N}$ & $\mathrm{n} / \mathrm{a}$ & $\mathrm{N}$ \\
\hline Oklahoma & $\mathrm{Y}$ & Some & $\mathrm{N}$ & $25,000 \mathrm{kWh}$ per year & $\mathrm{N}$ \\
\hline Oregon & $\mathrm{Y}$ & $\mathrm{Y}$ & $\mathrm{Y}$ & $25 \mathrm{~kW}$ various & $\mathrm{Y}$ \\
\hline Pennsylvania & $\mathrm{Y}$ & $\mathrm{N}$ & $\mathrm{N}$ & $\mathrm{n} / \mathrm{a}$ & $\mathrm{N}$ \\
\hline Rhode Island & $\mathrm{Y}$ & $\mathrm{N}$ & $\mathrm{n} / \mathrm{a}$ & $\mathrm{n} / \mathrm{a}$ & $\mathrm{N}$ \\
\hline South Dakota & $\mathrm{N}$ & $\mathrm{N}$ & $\mathrm{N}$ & $\mathrm{n} / \mathrm{a}$ & $\mathrm{N}$ \\
\hline Tennessee & $\mathrm{N}$ & $\mathrm{N}$ & $\mathrm{N}$ & $\mathrm{n} / \mathrm{a}$ & $\mathrm{N}$ \\
\hline Texas & $\mathrm{N}$ & $\mathrm{N}$ & $\begin{array}{c}\mathrm{N}(\text { Certain } \\
\text { municipalities } \\
\text { have } \\
\text { developed } \\
\text { their own) } \\
\end{array}$ & $\mathrm{n} / \mathrm{a}$ & $\mathrm{N}$ \\
\hline Utah & $\mathrm{Y}$ & $\mathrm{Y}$ & $\begin{array}{c}\mathrm{N}(\text { Certain } \\
\text { municipalities } \\
\text { have } \\
\text { developed } \\
\text { their own }) \\
\end{array}$ & $\mathrm{n} / \mathrm{a}$ & $\mathrm{N}$ \\
\hline Virginia & $\mathrm{Y}$ & $\mathrm{Y}$ & $\mathrm{N}$ & $\mathrm{n} / \mathrm{a}$ & $\mathrm{N}$ \\
\hline Vermont & $\mathrm{Y}$ & $\mathrm{Y}$ & $\mathrm{Y}$ & $\mathrm{n} / \mathrm{a}$ & $\mathrm{Y}$ \\
\hline Washington & $\mathrm{Y}$ & $\mathrm{Y}$ & $\mathrm{Y}$ & $\mathrm{n} / \mathrm{a}$ & $\mathrm{Y}$ \\
\hline Wisconsin & $\mathrm{Y}$ & $\mathrm{N}$ & $\mathrm{Y}$ & $20 \mathrm{~kW}$ & $\mathrm{~N}$ \\
\hline West Virginia & $\mathrm{Y}$ & $\mathrm{Y}$ & $\mathrm{Y}$ & $\begin{array}{l}25 \mathrm{~kW} \text { for certain } \\
\text { residential customers of } \\
\text { small IOUs, munis and } \\
\text { co-ops; } 50 \mathrm{~kW} \text { for non- } \\
\text { residential munis and } \\
\text { co-ops }\end{array}$ & Y \\
\hline Wyoming & $\mathrm{Y}$ & $\mathrm{Y}$ & $\mathrm{N}$ & $25 \mathrm{~W}$ & $\mathrm{~N}$ \\
\hline
\end{tabular}

\footnotetext{
${ }^{33}$ Some states do not have rural electric cooperatives. EIA: Table 10. Class of Ownership, Number of Consumers, Sales, Revenue, and Average Retail Price by State and Utility: All Sectors, 2009. www.eia.gov/cneaf/electricity/esr/table10.html. Accessed 6/23/2011.

${ }^{34}$ Some states do not have publicly owned (municipal) utilities or Public Utility Districts. EIA: Table 10. Class of Ownership, Number of Consumers, Sales, Revenue, and Average Retail Price by State and Utility: All Sectors, 2009. www.eia.gov/cneaf/electricity/esr/table10.html. Accessed 6/23/2011.

${ }^{35}$ The Policy Tool does not take into account states' net metering system size limits shown, only whether the policy is considered to be statewide. For example, Hawaii, Minnesota, Montana, Nebraska, Oregon, and West Virginia have system size limits that are below $100 \mathrm{~kW}$ for net metering, at least for certain utility types.
} 
Utility-specific net metering policies are not available in many states' rural areas, which often coincide with the best wind resources. For states without statewide net metering policies available to all customers, the Policy Tool's default assumption is that all electricity produced is sold or valued at avoided cost. The project team made this assumption because often, when net metering or utility-specific interconnection options are not available, distributed wind system production does not necessarily match up very well with a customer's load profile, and any excess would be valued at avoided cost. However, depending on several factors (especially the generation-to-load ratio and the seasonal and diurnal wind resource compared to on-site consumption), even without net metering policies in place, typically $40 \%$ to $80 \%$ of distributed wind generation can be used to offset retail consumption, with the remaining balance sold at avoided cost. To change the Policy Tool's avoided cost assumption, users can adjust the estimated percentage of energy that is consumed on-site and value that energy at the retail rate.

In some cases, the avoided cost value may show up as a credit on a customer's utility bill. In other cases, the utility actually issues checks to the customer. That distinction is not considered in the Policy Tool.

\section{Interconnection}

Actual interconnection costs vary widely from state to state and from utility to utility. The project team used the Federal Energy Regulatory Commission (FERC) SGIP fee structure as a starting point. ${ }^{36}$ Yet, because the fee structure only includes the application fee for the FERC SGIP and does not include any study fees, external disconnect fees, or other related costs, the project team amended the charges to be more representative of distributed wind interconnection costs.

The FERC SGIP has the following fee structure:

- For certified, inverter-based systems no larger than $10 \mathrm{~kW}$, the processing fee is $\$ 100$. Many states do not charge for small systems, but the interconnection process often takes time.

- For certified systems no larger than $2 \mathrm{MW}$ ("Fast Track"), the processing fee is $\$ 500$.

- The FERC standards do not address the issue of an external disconnect switch, but the Policy Tool includes an external disconnect switch cost of $\$ 200 .{ }^{37}$ When including installation, the cost may be substantially higher, especially for larger wind turbines.

Default values within the Policy Tool for interconnection costs are $\$ 300$ for systems $10 \mathrm{~kW}$ and smaller, $\$ 700$ for systems 11 to $20 \mathrm{~kW}, \$ 1,500$ for $50-\mathrm{kW}$ systems, and $\$ 6,000$ for $100-\mathrm{kW}$ systems.

However, interconnection costs are highly dependent on the project location, and some state regulations allow utilities to determine fees on a case-by-case basis. States, counties,

\footnotetext{
${ }^{36}$ Federal Energy Regulatory Commission. (2006). Order No. 2006 Standard Interconnection Agreements \& Procedures for Small Generators. www.ferc.gov/EventCalendar/Files/20050512110357-order2006.pdf

${ }^{37}$ The Solar ABCs report on External Disconnect Switches estimates that the average cost of a switch is between $\$ 200$ and $\$ 400$, but it can be much higher. www.solarabcs.org/about/publications/reports/ued/pdfs/ABCS05 studyreport.pdf, page 6.
} 
municipalities, and even utilities have different costs associated with interconnection. Additional cost factors include whether a dedicated transformer or other grid updates are required and whether the customer requires single-phase or three-phase power. Due to the rural nature of many distributed wind installations, the project team assumed higher interconnection costs. While many states have established standardized interconnection policies-including a standardized fee structure - many states do not, making it difficult to attribute a dollar amount to each state. Also inherent in interconnection procedures are soft and highly variable costs such as insurance requirements and timelines, which further complicate the cost basis for interconnection. This level of detail was beyond the scope of the project.

Best practices for interconnection policies and fees are provided in the Interstate Renewable Energy Council's "Model Interconnection Procedures."38 The Network for New Energy Choice's Freeing the Grid report ${ }^{39}$ is another important publication that grades states' net metering and interconnection policies, relative to the Interstate Renewable Energy Council's "Model Interconnection Procedures."

\section{Zoning}

The Policy Tool provides a default zoning and permitting cost of $\$ 300-\$ 2,500$, depending on the turbine choice and tower height. As with interconnection, zoning and permitting costs are highly variable depending on the location and are not easily determined. Policy Tool users can change the assumed fee and see the impact of streamlining the permitting process. Based on research and conversations with installers in various regions of the United States, predominantly rural states have substantially lower permitting costs than those with large urban centers (for example, fees in Montana and Idaho are much lower than in Washington and Oregon). Although California has led the way in funding distributed wind incentives, permitting requirements of many local jurisdictions there remain a market barrier. However, San Bernardino, Kern, and Solano Counties have passed favorable zoning regulations. Permitting fees for distributed wind turbines in California alone range from $\$ 0-\$ 10,000 .^{40}$

\section{Market Factors}

\section{Financing}

The default choice for project financing is $100 \%$ upfront equity investment, but the Policy Tool also allows users to model partial financing options. The following options are perhaps the most likely:

- All cash/equity purchase

- A standard 30-year, fixed-rate home mortgage loan, or more likely, a 15-year, home equity line of credit (assumed possible for residential turbines only)

- A low-interest loan offered by (or subsidized by) a state program.

\footnotetext{
${ }^{38}$ www.irecusa.org/wp-content/uploads/2010/01/IREC-Interconnection-Procedures-2010final.pdf

39 www.newenergychoices.org/uploads/FreeingTheGrid2010.pdf

40 http://cwec.ucdavis.edu/smallwindreports/documents/CWEC-2009-02-Permitting_Fees.pdf
} 


\section{Escalation Rates}

The project team used the EIA's Annual Energy Outlook 2010 projections ${ }^{41}$ to calculate a 20year (2010-2030) average gross domestic product (GDP) chain-type price index (1.018). This index was applied to the Policy Tool as an escalation rate on O\&M costs and electricity prices. Electricity prices are also multiplied by a national electricity price escalation index rate (1.004 for residential, 1.003 for commercial and non-taxed) based on the EIA's Annual Energy Outlook 2010 projections. For example, this means that the Policy Tool predicts that O\&M costs will increase $1.8 \%$ each year and electricity prices will increase $2.2 \%$ each year for the residential sector. Users may change these escalation rates if they wish to model other scenarios, as shown in the sensitivity analysis in Appendix C.

\section{Discount Rates}

Discount rates are used to relate present and future dollars, as the rates at which future values are diminished to account for the time value of money. Discount rate assumptions vary because different companies and individuals have different expectations of how capital can grow over time.

Based on a review of discount rates used in other policy tools, ${ }^{42}$ discussions with project advisors, and a sensitivity analysis (described in Appendix C), the project team used average rates from the Federal Reserve historical numbers database to serve as the Policy Tool's default discount rates. ${ }^{43}$

- Residential $=6 \%$ based on the 20-year Treasury Bill average rate for 1993-2009 44

- Commercial $=7 \%$ based on the prime average rate for 1990-2009

- Non-taxed $=5 \%$ based on the 20-year municipal bond (mixed quality) average rate for 19902009.

\section{State-Specific Issues}

California: California has two rebate programs: ERP and CA-SGIP. ERP, which was temporarily suspended in March 2011 and is expected to reopen in late 2011, is designed for turbines $50 \mathrm{~kW}$ and less, although the incentive is limited to the first $30 \mathrm{~kW}$ of capacity. CASGIP is for turbines $30 \mathrm{~kW}$ to $3 \mathrm{MW}$. When a turbine is eligible for both programs, the Policy Tool includes the greater incentive in the pro forma calculations. The Policy Tool is programmed to apply the correct default rebate value, depending on turbine size. Furthermore, both programs are rate-payer funded programs and available only to customers of the utilities that pay to support the programs. In the case of the ERP, customers of Pacific Gas \& Electric, Southern California Edison, San Diego Gas \& Electric, and Southern California Water (doing business as Bear Valley Electric Service) are eligible. In the case of the CA-SGIP, customers of San Diego

\footnotetext{
${ }^{41}$ www.eia.doe.gov/oiaf/aeo/pdf/0383(2010).pdf

${ }^{42}$ Lawrence Berkeley National Laboratory Policy Tool (2004): Residential $=8 \%$ break-even rate, $5.5 \%$ discount rate; ICF Policy Tool (2008): commercial $=$ prime $+2 \%=7 \%$, community $=8.25 \%=$ prime $+3.25 \%$, residential $=$ $8 \%$ (residential was not included in final report), public facilities $=4.90 \%=20$-year AAA-rate tax-exempt insured municipal bonds in June 2008.

${ }^{43}$ www.federalreserve.gov/releases/h15/data.htm\#top

44 The project team used historical averages, but in today's economy, many individuals may assume lower discount rates. One project advisor uses a discount rate of $1.5 \%$ to avoid indicating that distributed wind turbines are less financially attractive.
} 
Gas \& Electric, Pacific Gas \& Electric, Southern California Edison, or Southern California Gas are eligible. The Policy Tool assumes that these programs are available statewide.

Delaware: The state's utilities are responsible for implementing the Green Energy Program. The default values included within the Policy Tool are those for Delmarva Power \& Light (the state's only IOU). The Delmarva Power Green Energy Fund, established by state law and supported by ratepayers, funds the program.

Hawaii: In Hawaii, a wind energy system owner may select the state's FIT or choose to participate in its utility's net metering program, but not both. The Policy Tool's default setting for Hawaii is net metering. In either scenario, the Policy Tool also assumes that system owners are eligible for the state's renewable energy tax credit. In addition, Hawaii's net metering policy is considered to be statewide. There is a system capacity limit of $50 \mathrm{~kW}$ for Kauai Island Utility Cooperative, which is not taken into account. The default for net metering in Hawaii is "yes."

Idaho: Idaho's sales tax exemption is only applicable to systems $25 \mathrm{~kW}$ and greater.

Indiana: REC ownership is not addressed in Indiana's net metering policy, so the Policy Tool assumes the wind energy system owner owns the RECs produced.

Iowa: In Iowa, a wind energy system owner who receives the state PTC cannot also net meter. The default setting for Iowa therefore includes the PTC and does not include net metering.

Kansas: Kansas's income tax credit is assumed not to be applicable to the residential sector because the credit can only be taken by business owners.

Maine: Maine's Community-Based Renewable Energy Program provides eligible projects the option of selecting a long-term contract with a fixed maximum payment of $\$ 0.10 / \mathrm{kWh}$ or a REC multiplier. As of June 2011, four projects in Maine have been approved to receive this incentive (three have selected the long-term contract option and a maximum payment of $\$ 0.10 / \mathrm{kWh}$ and one selected the REC multiplier). ${ }^{45}$ The Policy Tool assumes that commercial and non-taxed wind energy system owners can receive the $\$ 0.10 / \mathrm{kWh}$ payment and the state rebate and sell RECs. Given the petition and application process, the Policy Tool assumes that the residential sector is ineligible.

Maryland: To receive Maryland's PTC, a wind energy system owner must be eligible for a minimum credit amount of $\$ 1,000$. The Policy Tool and the DSIRE data feed do not include this minimum requirement and therefore do not make this distinction. In reality, most of the residential sector turbines included in the Policy Tool are probably ineligible for this credit because they fail to meet the minimum amount.

Massachusetts: The Commonwealth Wind Incentive Program - Micro Wind Initiative is determined by a formula that cannot be included in the DSIRE quantitative feed, so it is hard coded and calculated directly in the Policy Tool. In addition, a percentage (90\%) of the rebate is paid up-front based on expected performance, and the remaining (10\%) is paid after 1 year of

\footnotetext{
${ }^{45}$ Maine Public Utilities Commission, Community-Based Renewable Energy Pilot Program. www.state.me.us/mpuc/electricity/community_pilot.shtml. Accessed 6/4/2011.
} 
actual production. The Policy Tool assumes it is all paid up-front. The initiative supports turbines $1 \mathrm{~kW}$ to $99 \mathrm{~kW}$; 100-kW turbines are not eligible for this rebate, but they are eligible for a grant under a separate program that is not included in the Policy Tool. Furthermore, the Commonwealth Wind Incentive Program - Micro Wind Initiative is funded by the Renewable Energy Trust. Not all utilities in the state contribute to the fund. Projects must be served by one of the investor-owned electric distribution utilities in Massachusetts: Fitchburg Gas and Electric Light (Unitil), Massachusetts Electric (National Grid), Nantucket Electric (National Grid), NSTAR Electric, or Western Massachusetts Electric. In addition, certain Municipal Light Plant departments have opted to pay into the Renewable Energy Trust, and their customers are eligible for the rebates. These include Ashburnham, Holden, Holyoke, Russell, and Templeton. ${ }^{46}$ Only the residential sector is eligible for Massachusetts's sales tax exemption.

Minnesota: Minnesota's state net metering policy applies to all IOUs, municipal utilities, and electric cooperatives. The Policy Tool default for net metering in the state is "yes," although there is a $40-\mathrm{kW}$ system capacity cap on net metering. The Policy Tool does not take this into account.

Montana: Montana's state net metering policy only applies to IOUs, but most cooperatives have also adopted net metering, so the Policy Tool assumes statewide net metering is available in Montana. The Policy Tool does not take into account system capacity limits for net metering, which for most cooperatives is $10 \mathrm{~kW}$.

Nebraska: Nebraska's sales tax exemption for wind energy systems only applies to community wind projects and is therefore not included in the default assumptions in the Policy Tool. Nebraska is also assumed to have statewide net metering, although in reality there is a system capacity limit of $25 \mathrm{~kW}$. The Policy Tool does not take that limit into account.

Nevada: If a wind energy system owner receives a state rebate from the NV Energy program, ownership of the system's RECs transfers to NV Energy. Therefore, the default assumes no REC sales.

New Jersey: The New Jersey rebate is determined by incremental rates based on estimated kWh production that cannot be included in the DSIRE quantitative feed (based on the feed's current structure), so it is calculated directly in the Policy Tool. Only certain turbines are eligible to receive New Jersey's rebate, but the Policy Tool assumes that all turbine options provided are eligible.

New Mexico: The default assumptions for New Mexico are no statewide net metering and no REC sales. Wind energy system owners who net meter cannot sell their RECs because the utility owns any RECs associated with net metering.

New York: Like New Jersey, New York's rebate is determined by incremental rates based on estimated $\mathrm{kWh}$ production that cannot be included in the DSIRE quantitative feed, so it is calculated directly in the Policy Tool. Only certain turbines are eligible to receive New York's

\footnotetext{
${ }^{46}$ Commonwealth Wind Program. www.masscec.com/index.cfm/page/Municipal-Lighting-PlantCommunities/cdid/11387/pid/11163. Accessed 6/6/2011.
} 
rebate, but the Policy Tool assumes that all turbine options provided are eligible. When a wind energy system owner receives a rebate, NYSERDA owns the system's RECs for the first 3 years of the project life. For this reason, REC sales are not included in the default settings for New York. NYSERDA funds the program with an RPS surcharge; only customers of electricity distribution utilities that collect the RPS surcharge (including Central Hudson Gas \& Electric, Consolidated Edison Company of New York, New York State Electric \& Gas, National Grid, Orange and Rockland Utilities, and Rochester Gas \& Electric) are eligible for program incentives. The Policy Tool assumes that it is a statewide rebate.

Ohio: The sales tax exemption on wind energy systems in Ohio is only applicable to the commercial and non-taxed sectors.

Oregon: Oregon's maximum residential energy tax credit for wind energy systems is $\$ 1,500$ a year for 4 years, for a total of $\$ 6,000$. If a wind energy system owner receives a state rebate, the state owns the system's RECs for years 3 through 16 of the project life. For this reason, REC sales are not included in the default settings for Oregon. Only certain turbines are eligible to receive Oregon's rebate, but the Policy Tool assumes that all turbine options provided are eligible. In addition, Oregon is considered to have statewide net metering, but in reality Oregon has established separate net-metering programs for the state's primary IOUs (PGE and PacifiCorp) and for its public utilities with different maximum system capacity limits. System capacity limits for customers of PGE and PacifiCorp customers are $2 \mathrm{MW}$ for non-residential and $25 \mathrm{~kW}$ for residential; for customers of municipal utilities, cooperatives, and public utility districts, the system capacity limits are $25 \mathrm{~kW}$ for non-residential and $10 \mathrm{~kW}$ for residential. These system capacity limits are not taken into account in the Policy Tool for net metering.

Utah: Utah's sales tax exemption is only applicable to systems $20 \mathrm{~kW}$ and greater.

Vermont: In Vermont, a wind energy system owner cannot receive both the Vermont Standard Offer PBI (the state's FIT, which is currently fully subscribed) and a state rebate. A system owner can take the state rebate, net meter, and sell RECs, which is the default setting for Vermont.

Washington: The state's business and occupation tax is not included in data on state income tax rates from the Federation of Tax Administrators used in the Policy Tool's default assumptions and was not taken into account for the case studies in the guidebook and this report.

Wisconsin: The Focus on Energy rebate is determined by a formula based on the eligible turbine's estimated energy production that cannot be included in the DSIRE quantitative feed, so it is calculated directly using the power curves in the Policy Tool. The exact rebate amounts offered by the Wisconsin program are calculated using non-public power curves, so they may vary from the rebates calculated by the Policy Tool. A bonus incentive is available to wind energy system owners who also implement energy efficiency projects, but that bonus is not included in the Policy Tool. The bonus incentive for non-profits is included for the non-taxed sector. Only certain turbines and tower heights are eligible to receive the Focus on Energy rebate, but the Policy Tool assumes that all turbine options provided are eligible. 


\section{Results and Discussion}

The Policy Tool's underlying financial pro forma model measures the impacts of various policy combinations on distributed wind project economics within existing tax and electricity rates and can be used to rank the "best" and "worst" state environments for distributed wind. The Policy Tool allows each state's incentives to be modeled for a variety of ownership sectors, turbines, and wind resources. The Policy Tool then calculates the COE, NPV, IRR, and simple payback for each scenario (definitions included in Appendix D).

Designed for broad policy analysis, the Policy Tool is not designed for project-specific siting and is not capable of addressing site-specific variables, although it can provide important insights into project economics for consumers.

It is important to consider all four financial metrics when looking at the impact of a set of policies on a specific turbine at a specific site. This is because some incentives do not impact the cash flows of a distributed wind project and others do not reduce the system's costs. For example, the sale of RECs improves the cash flows of a project, but it does not impact the COE. The COE takes into account equipment and installation costs, sales taxes, rebates (capacity and performance-based), grants, income tax credits and deductions, and the tax shield effect of depreciation and loan interest payments. In other words, the COE takes into account all upfront system costs. Other project indicators (IRR, NPV, and simple payback) take into account REC sales, FIT payments, net metering, and other ongoing cash flows.

\section{Ranking of States}

As the baseline case study, the project team ranked all of the states based on their policies and incentives (with the Policy Tool's default settings) as of November 2011. The COE results for each sector are shown in Figure 4.

It is important to note that this ranking exercise is a moving target. Since the ranking below was originally prepared, a number of state incentives have changed or are in the process of change. For example, new guidelines are in place for both of California's incentives programs, revised rules are under consideration in New Jersey and Oregon, and Nevada's rebate program is fully subscribed.

Also, this ranking does not take into account all market factors. The Distributed Wind Energy Association has identified California, New York, Ohio, Nevada, Oregon, Texas, and New Jersey as the nation's top markets.47 Although modeling Oregon's tax credit, rebates, and lack of sales tax effectively resulted in the lowest COE in the nation for the residential sector, the distributed wind industry continues to face challenges there. The Energy Trust of Oregon's rebates are limited to customers of IOUs, and as of November 2011, Oregon's statewide commercial tax credit has been substantially scaled back and is allocated on a first-come, first-served basis, so is not available to most projects. 


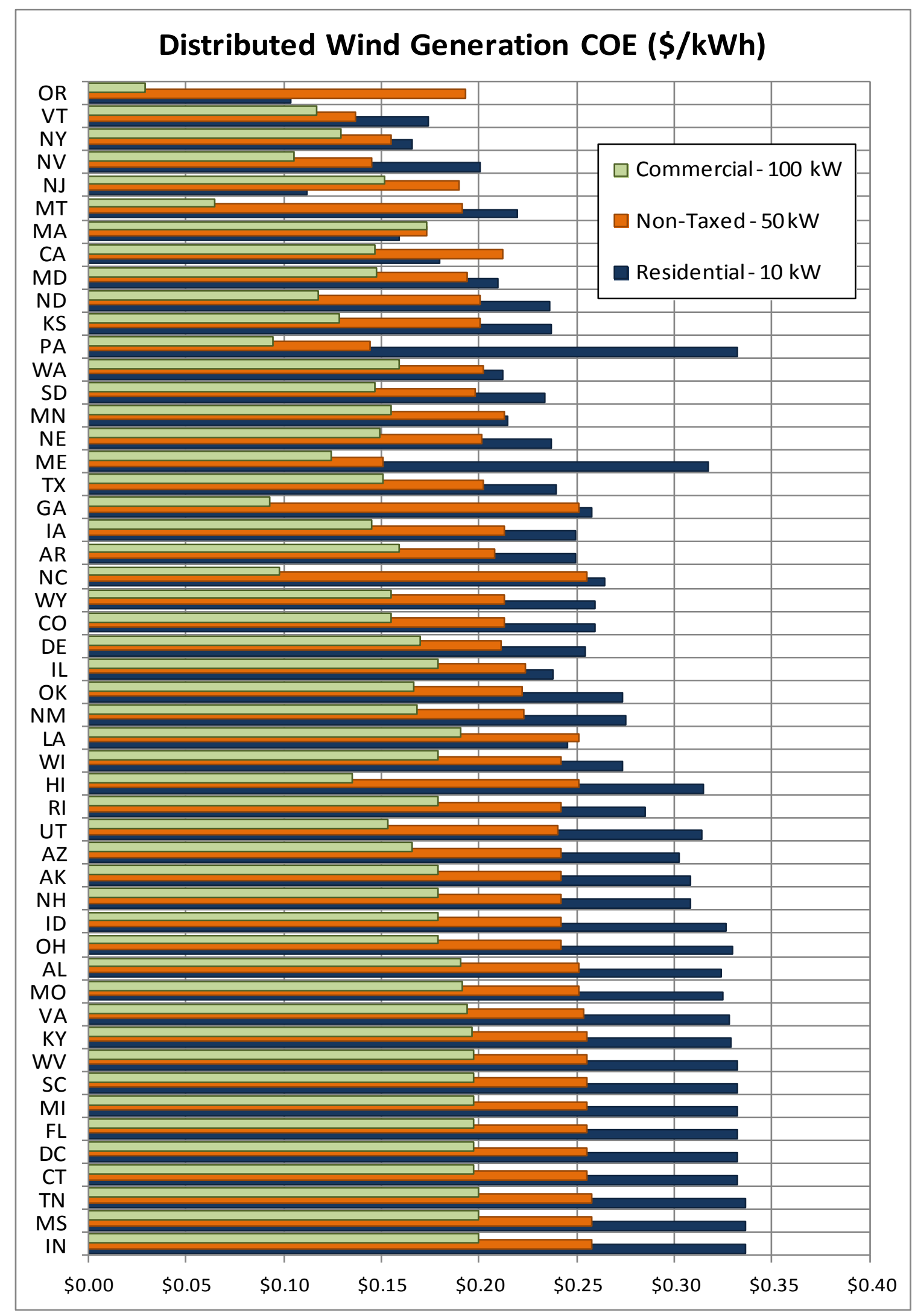

Figure 4 Average COE results of base case scenarios (as of November 2011)

Final Technical Report: Power through Policy: "Best Practices" for Cost-Effective Distributed Wind | 23 


\section{Net Metering}

Net metering is a popular and administratively simple policy option for states. Net metering allows electric customers who generate their own electricity to bank excess electricity on the grid, usually in the form of kWh credits. These credits are used to offset electricity consumed by the customer at a different time (i.e., when the customer's wind energy system is not generating enough electricity to meet the customer's needs). In effect, the customer uses excess generation credits to offset electricity that the customer otherwise would have to purchase at the utility's full retail rate. Net metering is typically accomplished through the use of a single, conventional, bidirectional meter. ${ }^{47}$

Like most other policies, the effectiveness of a net metering policy depends heavily on the individual provisions that specify how it is applied. In other words, it is not just a matter of allowing net metering; the details and accessibility of the policy make big differences. Net metering best practices information is provided in the Interstate Renewable Energy Council's "Model Net Metering Rules." 48

The Policy Tool does not factor in net excess generation rollover provisions, customer eligibility, or several other provisions. Instead, the Policy Tool only considers whether the policy applies to IOUs only or to all utilities in a state, including public utilities and electric cooperatives. Because many distributed wind installations are best sited in rural areas typically served by public utilities and cooperatives, net metering is a default in the Tool when it is available statewide.

For this case study, the project team assumed that net metering was the default policy option in all states and compared the potential economic returns to the base case scenario. Results show that net metering benefits states with higher electricity costs more than those with cheaper electricity in all sectors (residential, commercial, and non-taxed) due to the assumption that under statewide net metering, all wind energy generation consumed on-site replaces electricity that would have otherwise been purchased at the retail rate. The top states for NPV correspond closely to the top states that feature the highest electricity prices. Table 2 shows the top 10 states ranked according to NPV when net metering is applied to all states for a $100-\mathrm{kW}$ commercialsector turbine, and Table 3 shows the states with the highest retail electricity rates. Seven states appear in both lists, suggesting a strong correlation between retail electricity prices and the value of net metering to a project's economics.

Additionally 32 states have a negative IRR in the base case scenario for a $100-\mathrm{kW}$ commercial turbine, whereas only four states have a negative IRR when net metering is applied to all states. These four states (Idaho, Kentucky, Missouri, and West Virginia) only have slightly negative IRRs (between $-1 \%$ and $-2 \%$ ), whereas the 32 base case scenario states ranged from $-1 \%$ to $-9 \%$. The four states with negative IRRs under net metering are among the states with the cheapest electricity in the United States.

Because net metering does not affect the upfront cost of a system, it does not impact the COE, yet it does have a significant positive impact on the overall project economics. The project team

\footnotetext{
${ }^{47}$ One state (Maine) technically has "net billing," but it is essentially the same as net metering. Some individual utility policies that are not state-jurisdictional may be considered "net billing," with varying definitions.

${ }^{48}$ www.irecusa.org/fileadmin/user_upload/ConnectDocs/IREC_NM_Model_October_2009-1.pdf
} 
chose to highlight Texas as an example, which has earned the distinction of having "worst practices" when it comes to net metering. ${ }^{49}$ In 2007, the Texas legislature enacted a law with the aim of increasing the eligibility of net metering. But because net metering was not defined in the law, the subsequent regulatory process and rules actually removed net metering for the state. As Table 4 illustrates, this rulemaking resulted in a disincentive for those with distributed wind energy systems. Net metering applied to a commercial $(100-\mathrm{kW})$ turbine in Texas decreases the simple payback from more than 20 to 12 years. For the residential sector $(11 \mathrm{~kW})$, the IRR changes from $-7 \%$ to $2 \%$. The non-taxed sector (50 kW) improves from an IRR of $-8 \%$ to $1 \%$.

Table 2 Project Economics for a 100-kW Commercial Turbine (with Net Metering Applied)

\begin{tabular}{|c|c|c|c|c|}
\hline State & COE & NPV & IRR & $\begin{array}{c}\text { Simple } \\
\text { Payback } \\
\text { Years) }\end{array}$ \\
\hline Hawaii & $\$ 0.135$ & $\$ 345,391$ & $17 \%$ & 5 \\
\hline New York & $\$ 0.129$ & $\$ 142,127$ & $13 \%$ & 6 \\
\hline Nevada & $\$ 0.086$ & $\$ 72,300$ & $11 \%$ & 6 \\
\hline Vermont & $\$ 0.116$ & $\$ 71,884$ & $10 \%$ & 7 \\
\hline Maine & $\$ 0.124$ & $\$ 64,278$ & $9 \%$ & 9 \\
\hline New Jersey & $\$ 0.151$ & $\$ 52,485$ & $9 \%$ & 9 \\
\hline Connecticut & $\$ 0.197$ & $\$ 36,212$ & $8 \%$ & 10 \\
\hline Rhode Island & $\$ 0.179$ & $\$ 32,045$ & $8 \%$ & 9 \\
\hline Massachusetts & $\$ 0.173$ & $\$ 23,706$ & $8 \%$ & 10 \\
\hline California & $\$ 0.147$ & $\$ 21,918$ & $8 \%$ & 9 \\
\hline
\end{tabular}

Table 3 States with Highest Electricity Prices

\begin{tabular}{|c|c|}
\hline State & $\begin{array}{c}\text { Commercial Sector } \\
\text { Average Retail } \\
\text { Price, 2011 }\end{array}$ \\
\hline Hawaii & $\$ 0.28$ \\
\hline Connecticut & $\$ 0.16$ \\
\hline New York & $\$ 0.16$ \\
\hline Alaska & $\$ 0.15$ \\
\hline Massachusetts & $\$ 0.14$ \\
\hline New Hampshire & $\$ 0.14$ \\
\hline Vermont & $\$ 0.14$ \\
\hline New Jersey & $\$ 0.13$ \\
\hline Rhode Island & $\$ 0.13$ \\
\hline District of Columbia & $\$ 0.13$ \\
\hline
\end{tabular}

\footnotetext{
${ }^{49}$ Network for New Energy Choices. 2010. Freeing the Grid. www.newenergychoices.org/uploads/FreeingTheGrid2010.pdf
} 
Table 4 Project Economics for Texas (with and without Net Metering)

\begin{tabular}{|c|c|c|c|c|c|c|}
\hline \multicolumn{4}{|c|}{ Case Study: Texas with Net Metering } & \multicolumn{3}{|c|}{ Base Case: Texas without Net Metering } \\
\hline $\begin{array}{l}\text { Sector and } \\
\text { Turbine }\end{array}$ & NPV & IRR & $\begin{array}{l}\text { Simple Payback } \\
\text { (Years) }\end{array}$ & NPV & IRR & $\begin{array}{l}\text { Simple Payback } \\
\text { (Years) }\end{array}$ \\
\hline $\begin{array}{l}\text { Commercial } \\
100-\mathrm{kW} \text { Northwind }\end{array}$ & $(\$ 38,706)$ & $6 \%$ & 12 & $(\$ 222,438)$ & $-3 \%$ & More than 20 \\
\hline $\begin{array}{l}\text { Residential } \\
11-\mathrm{kW} \text { G11 }\end{array}$ & $(\$ 35,016)$ & $2 \%$ & 17 & $(\$ 78,818)$ & $-7 \%$ & More than 20 \\
\hline $\begin{array}{l}\text { Non-Taxed } \\
50-k W \text { E3120 }\end{array}$ & $(\$ 105,224)$ & $1 \%$ & 19 & $(\$ 260,184)$ & $-8 \%$ & More than 20 \\
\hline
\end{tabular}

\section{Feed-In Tariffs}

FITs provide price-transparency to system owners and therefore enable a good projection of project revenue prior to incurring any costs in developing a site or installing a system. FITs have not been widely adopted in the United States as compared with countries in Europe and elsewhere due to the regulatory complexity that surrounds them. Policymakers typically aim to provide a payment level that is sufficiently high to spur renewable development when designing a FIT. This can be difficult, however, because a FIT price that adequately compensates one installation may under- or over-compensate another installation.

A FIT price that aims to compensate all installations may generate interest that exceeds program availability, as has been the case for many FIT programs that quickly become fully subscribed or "sold out" the same day that the program opens. Hawaii, on the other hand, set a FIT price that was less than the retail price of electricity, which elicited an underwhelming response from project developers. ${ }^{50}$ In this case, when available, it makes more sense to opt for net metering, which compensates excess energy at the full retail value of electricity. Likewise, an existing FIT program in California has made little impact because prices were pegged to wholesale fossil power and therefore were not sufficient to spur small wind or solar PV projects.

Moreover, because FITs are wholesale energy policies (i.e., all energy is sold, as compared to a retail policy like net metering, where energy is used on-site), the Federal Power Act must be considered as states contemplate FITs. ${ }^{51}$ While the issue is complex, FITs are affected by FERC's jurisdiction to set rates and conditions for the sale or resale of electricity. States have other means of approximating FITs, however, through mechanisms like mandatory REC purchases and preferential rate setting under a state RPS. But these state approaches lack the simplicity and appeal of FITs that have been so successful in Europe. However, budgetconscious governments in Europe are reducing FITs. It is also doubtful under current economic

\footnotetext{
${ }^{50} 2010$ DWT Policy Questionnaire Results, Power through Policy: 'Best Practices' for Cost-Effective Distributed Wind, U.S. Department of Energy Award DE-EE0000503, eFormative Options; see also www.renewableenergyfocususa.com/view/14933/comment-little-interest-in-hawaii-feedin-tariff-program-saysreport

${ }^{51}$ Hawaii, Alaska and most of Texas may be exempted from the federal preemption, however, because transmission lines in these states do not cross state borders. For more information, see

Renewable Energy Prices in State-Level Feed-in Tariffs: Federal Law Constraints and Possible Solutions, available at www.nrel.gov/docs/fy10osti/47408.pdf
} 
conditions that FIT rates will soon be as lucrative to end-users in the United States as in Europe and Nova Scotia, which will soon launch a Community FIT rate of $\$ 0.459 / \mathrm{kWh}^{52}$

The following case study demonstrates the impact a national FIT could have on distributed wind project economics across the United States by presenting the residential sector results for a few states' current policy environments chosen to represent different regions of the country. When a project owner elects to participate in a FIT program, the owner is not also eligible to participate in a net metering program. In addition, the RECs associated with the energy sold through a FIT are typically transferred as part of the FIT. Therefore, the FIT case study assumes no net metering or REC sales in any of the states, but all other incentive programs were left intact.

Figure 5 shows the positive impact of increasing FIT rates in the United States on a residential project's IRR for each of the selected states for a 10-kW Bergey turbine. The scenarios were modeled on FIT levels of $\$ 0.15, \$ 0.25$, and $\$ 0.50$ per $\mathrm{kWh}$. Table 5 shows the project economic metrics for a 2.4-kW residential turbine under the same FIT scenarios.

\section{FIT Scenarios}

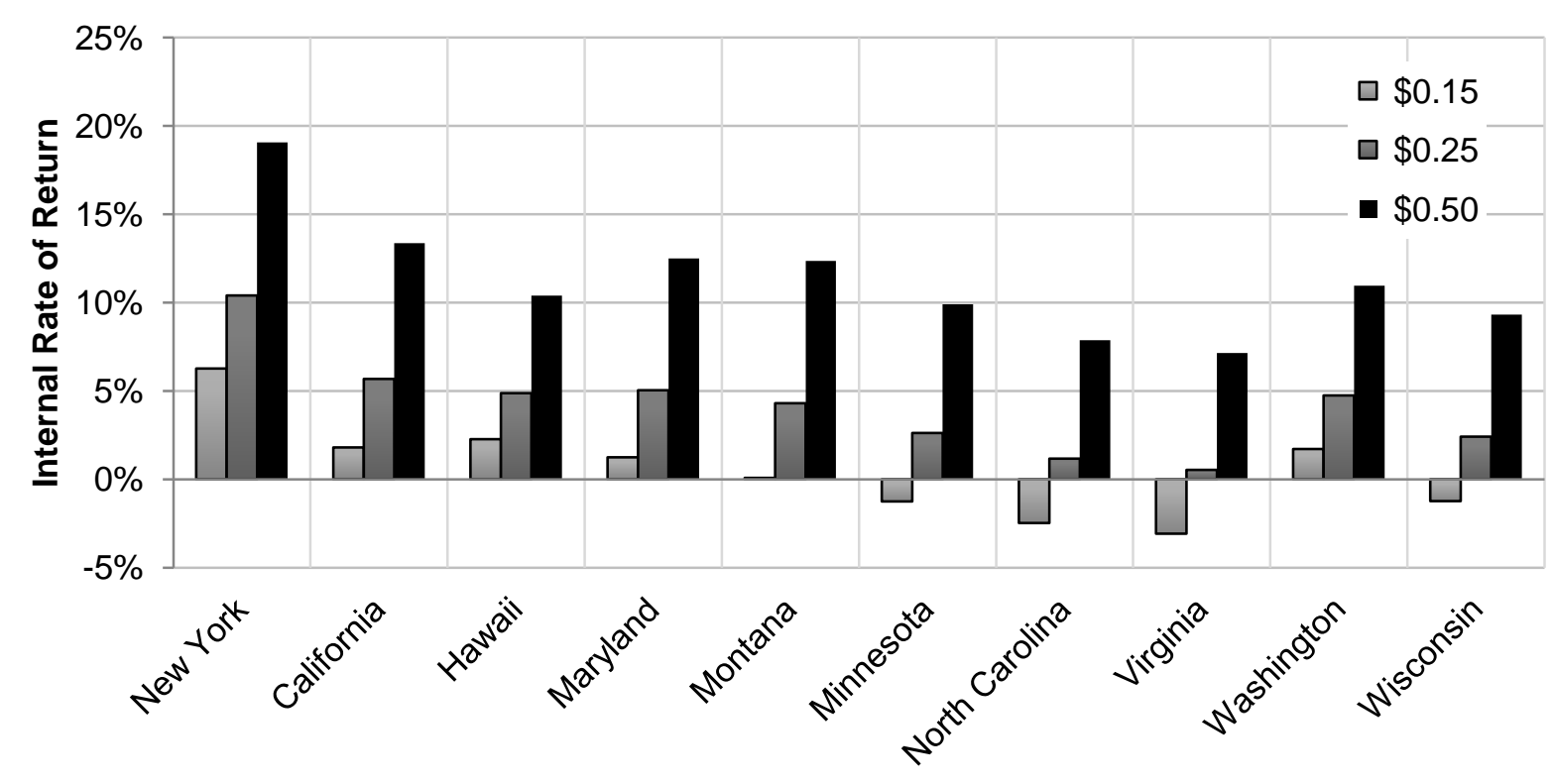

Figure 5 Select IRR results of modeling FIT rates for the residential sector (10-kW turbine)

Given that the FIT is not a cost, but a revenue stream, it does not affect the scenario's COE. The project economic metrics clearly improve as the level of the FIT increases. For states with few policies or incentives beneficial to distributed wind, such as Virginia, it would take a hefty FIT of $\$ 0.50 / \mathrm{kWh}$ to achieve positive project economics. For states with strong incentives, such as New York, it is possible to achieve positive project economics with a lower FIT rate, assuming the incentives would continue at the same level.

\footnotetext{
${ }^{52}$ http://nsrenewables.ca/feed-tariffs
} 
However, no change happens in a vacuum. Incentives are often adjusted when new policies are adopted, and rules against double-dipping may be implemented to prevent projects from receiving both a FIT and other incentives. When the federal tax credit limit was removed for PV systems, NYSERDA considered reducing its incentive to absorb $100 \%$ of this change but eventually settled on $75 \%$. Similarly, as the cost of PV systems has decreased, NYSERDA's incentives were reduced accordingly.

As an additional "what if" exercise, New York's FIT case study results were examined without the state rebate and the federal ITC, as shown in Figure 6. In this example, New York's IRR for both $2.4-\mathrm{kW}$ and $10-\mathrm{kW}$ turbines would only become positive with a $\$ 0.25 / \mathrm{kWh}$ FIT, and $\$ 0.50 / \mathrm{kWh}$ would result in a $7 \%$ IRR. One interesting aspect about FITs is that the non-taxed sector fares better than both the commercial and residential sectors due to taxation issues.

Table 5 Select Results of Modeling Various FIT Rates for the Residential Sector (2.4-kW Turbine)

\begin{tabular}{|c|c|c|c|c|c|c|c|c|c|c|c|}
\hline \multirow{2}{*}{$\begin{array}{c}\text { FIT } \\
\text { Rate, } \\
\text { \$/kWh }\end{array}$} & $\begin{array}{l}\text { Wind } \\
\text { Resource }\end{array}$ & $\begin{array}{c}\text { Low } \\
\text { Class } 2 \\
\end{array}$ & $\begin{array}{c}\text { Low } \\
\text { Class } 2\end{array}$ & $\begin{array}{c}\text { Low } \\
\text { Class } 2 \\
\end{array}$ & $\begin{array}{c}\text { Mid } \\
\text { Class } 2 \\
\end{array}$ & $\begin{array}{c}\text { Low } \\
\text { Class } 3\end{array}$ & $\begin{array}{c}\text { Low } \\
\text { Class } 2 \\
\end{array}$ & $\begin{array}{c}\text { Low } \\
\text { Class } 2\end{array}$ & $\begin{array}{c}\text { Low } \\
\text { Class } 2 \\
\end{array}$ & $\begin{array}{c}\text { Low } \\
\text { Class } 2\end{array}$ & $\begin{array}{c}\text { Low } \\
\text { Class } 2\end{array}$ \\
\hline & $\begin{array}{l}\text { COE, } \\
\$ / k W h\end{array}$ & $\$ 0.27$ & $\$ 0.38$ & $\$ 0.24$ & $\$ 0.19$ & $\$ 0.28$ & $\$ 0.38$ & $\$ 0.26$ & $\$ 0.42$ & $\$ 0.30$ & $\$ 0.31$ \\
\hline \multirow{3}{*}{$\$ 0.15$} & NPV, \$ & $(\$ 2,990)$ & $(\$ 4,028)$ & $(\$ 1,834)$ & $(\$ 1,201)$ & $(\$ 5,741)$ & $(\$ 6,122)$ & $(\$ 5,693)$ & $(\$ 8,864)$ & $(\$ 4,903)$ & $(\$ 4,811)$ \\
\hline & IRR & $2 \%$ & $0 \%$ & $3 \%$ & $4 \%$ & $0 \%$ & $-1 \%$ & $-1 \%$ & $-4 \%$ & $1 \%$ & $0 \%$ \\
\hline & $\begin{array}{l}\text { Payback, } \\
\text { yrs }\end{array}$ & 17 & 17 & 15 & 14 & $>20$ & $>20$ & $>20$ & $>20$ & 18 & $>20$ \\
\hline \multirow{3}{*}{$\$ 0.25$} & NPV, \$ & $(\$ 392)$ & $(\$ 1,452)$ & $\$ 799$ & $\$ 2,427$ & $(\$ 2,011)$ & $(\$ 3,553)$ & $(\$ 3,135)$ & $(\$ 6,223)$ & $(\$ 2,155)$ & $(\$ 2,233)$ \\
\hline & IRR & $0 \%$ & $0 \%$ & $7 \%$ & $9 \%$ & $4 \%$ & $2 \%$ & $2 \%$ & $0 \%$ & $4 \%$ & $2 \%$ \\
\hline & $\begin{array}{l}\text { Payback, } \\
\text { yrs }\end{array}$ & 12 & 13 & 11 & 9 & 14 & 16 & 16 & $>20$ & 14 & 15 \\
\hline \multirow{3}{*}{$\$ 0.50$} & NPV, \$ & $\$ 6,105$ & $\$ 4,990$ & $\$ 7,384$ & $\$ 11,495$ & $\$ 7,314$ & $\$ 2,870$ & $\$ 3,261$ & $\$ 378$ & $\$ 4,712$ & $\$ 4,210$ \\
\hline & IRR & $0 \%$ & $10 \%$ & $15 \%$ & $19 \%$ & $12 \%$ & $9 \%$ & $9 \%$ & $6 \%$ & $10 \%$ & $10 \%$ \\
\hline & $\begin{array}{l}\text { Payback, } \\
\text { yrs }\end{array}$ & 7 & 9 & 6 & 5 & 8 & 10 & 9 & 11 & 9 & 8 \\
\hline
\end{tabular}




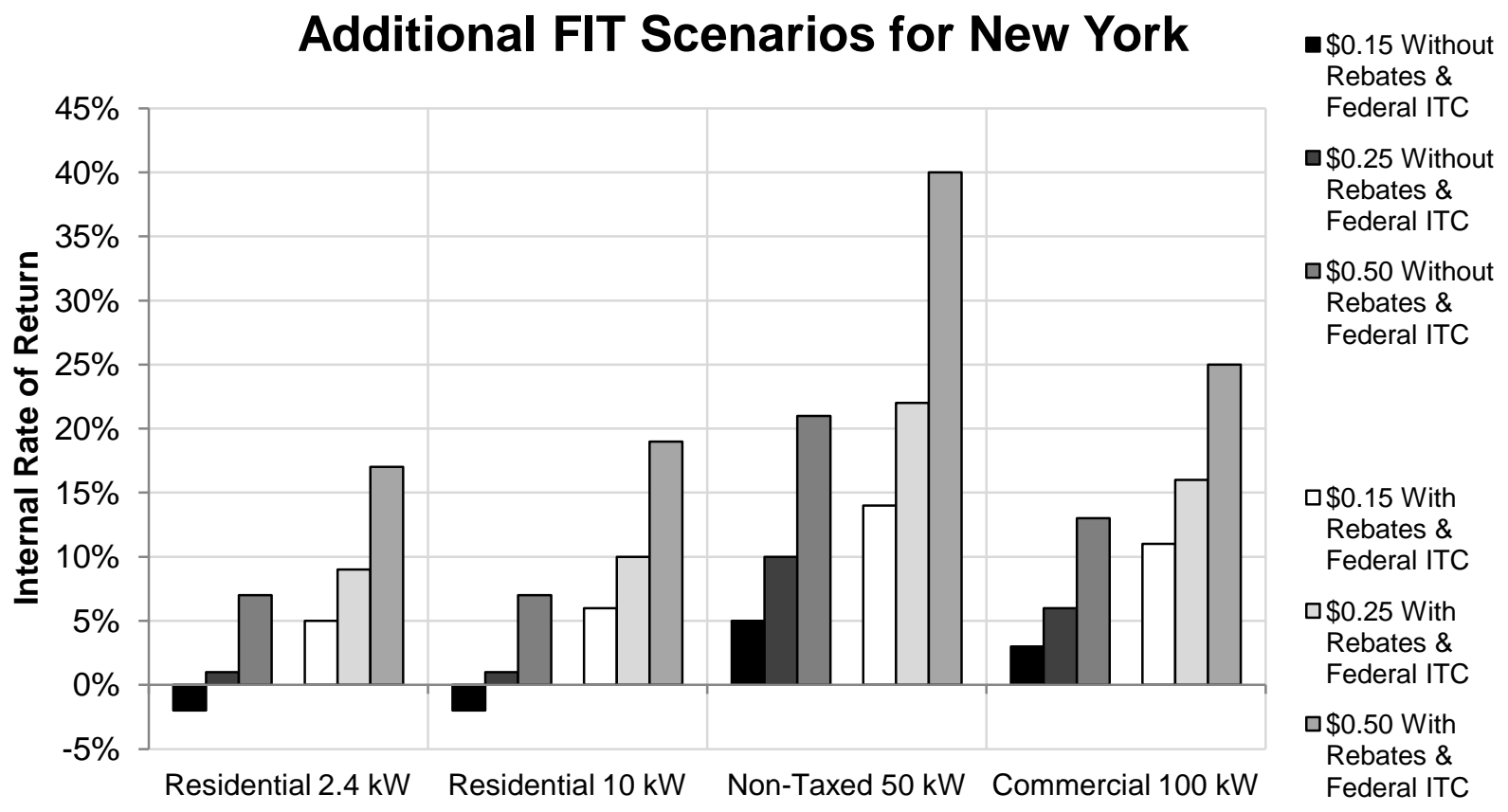

Figure 6 Comparison of New York case study results with and without rebates and federal ITC

\section{Tower Height Restrictions}

Wind turbines at greater heights can access higher wind speeds, which in turn allows for higher energy production. It is therefore important to consider any height restrictions in the area of a proposed wind project because project economics may be impacted.

Surrounding vegetation, buildings, and topography can block the wind or increase its turbulence. Therefore, a simple rule of thumb for distributed wind systems is to site the turbine at least 30 feet above any surrounding obstructions within 500 feet. ${ }^{53}$ However, some jurisdictions have strict height limits, such as 45 feet, that ignore the issue of obstructions, while some states have more progressive permitting standards.

California and New Hampshire have statewide permitting rules that preclude municipalities from passing height restrictions more restrictive than the limit set by the state. California's Assembly Bill 45 provides guidelines for wind ordinances that are passed after January 1, 2011, to cover distributed wind systems (50 kW or less) outside of urban areas but still within a county's jurisdiction. Tower heights in these ordinances cannot be set at less than 80 feet on lots between 1 and 5 acres and less than 100 feet on lots more than 5 acres. ${ }^{54}$ In 2008, New Hampshire passed legislation that prevents municipalities from creating ordinances for distributed wind (100 $\mathrm{kW}$ or less) with restrictions that the state has identified as unreasonable. The technical bulletin required by this legislation sets 150 feet as the maximum tower height, but it notes that local ordinances should allow the wind turbines to reach 35 feet taller than surrounding vegetation. ${ }^{55}$ States that

\footnotetext{
${ }^{53}$ www.renewwisconsin.org/wind/ToolboxHomeowners/Rules\%20of\%20Thumb\%20for\%20Tower\%20Heights.pdf

${ }_{55}^{54}$ www.leginfo.ca.gov/pub/09-10/bill/asm/ab_0001-0050/ab_45_bill_20091011_chaptered.pdf

55 www.nh.gov/oep/resourcelibrary/swes/documents/technical_bulletin.pdf
} 
pass such rules are ensuring that local municipalities will not pass overly restrictive ordinances to prevent or impair wind development in their jurisdictions.

Another option for states and local municipalities is to specify setbacks for wind projects in a way that does not require a specific height limit or minimum lot size. The North Carolina model wind ordinance uses this approach by specifying different setbacks for what it considers small (20 kW or less), medium $(20 \mathrm{~kW}-100 \mathrm{~kW})$, and large (100 kW or more) turbines. The setbacks are based on the height of the tip of the blade, at its highest elevation, when measured from the ground at the center of the tower. In this way, restrictions are placed on the proximity of the turbine to occupied buildings, property lines, and public roads. Under this type of ordinance, taller towers will be allowed on larger parcels of land, a reasonable approach that may represent a best practice for policymakers.

A growing number of incentive programs base payments on production, in which the wind energy system owner receives an incentive $(\$ / \mathrm{kWh})$ based on the system's energy production. Higher towers capture higher wind speeds, which results in higher energy production. The Policy Tool allows users to see the impact that different tower heights have on project economics, and this case study looks at some examples.

Under New York's three-tiered incentive program, a customer receives one rate for a system's estimated first 10,000 kWh produced in a year, a second rate for the system's estimated production above $10,000 \mathrm{kWh}$ up to $115,000 \mathrm{kWh}$, and a third rate for the system's estimated production above $115,000 \mathrm{kWh}$ up to $125,000 \mathrm{kWh}$. An analysis of a 50-kW commercial-sector turbine in New York shows that the resulting increased estimated production from the turbine on a taller tower increases the rebate amount and substantially decreases the COE, as shown in Table 6.

Table 6 Project Economics for a Commercial-Sector 50-kW Turbine in New York

\begin{tabular}{|c|c|c|c|c|c|c|c|c|}
\hline $\begin{array}{c}\text { Sector and } \\
\text { Turbine }\end{array}$ & $\begin{array}{c}\text { Wind } \\
\text { Resource }\end{array}$ & $\begin{array}{c}\text { Hub } \\
\text { Height }\end{array}$ & $\begin{array}{c}\text { Energy } \\
\text { Production }\end{array}$ & COE & NPV & IRR & $\begin{array}{c}\text { Simple } \\
\text { Payback } \\
\text { (Years) }\end{array}$ & $\begin{array}{c}\text { Rebate } \\
\text { Amount }\end{array}$ \\
\hline $\begin{array}{c}\text { NY } \\
\text { Commercial } \\
50 \mathrm{~kW}\end{array}$ & $\begin{array}{c}\text { Low Class } \\
2\end{array}$ & $120 \mathrm{ft}$ & $\begin{array}{c}116,195 \\
\mathrm{kWh} / \mathrm{yr}\end{array}$ & $\$ 0.099$ & $(\$ 12,664)$ & $6 \%$ & 11 & $\$ 141,195$ \\
\cline { 2 - 10 } & $\begin{array}{c}\text { Low Class } \\
2\end{array}$ & $140 \mathrm{ft}$ & $\begin{array}{c}125,293 \\
\mathrm{kWh} / \mathrm{yr}\end{array}$ & $\$ 0.074$ & $\$ 19,422$ & $9 \%$ & 8 & $\$ 150,088$ \\
\hline
\end{tabular}

Wisconsin's Focus on Energy rebate program takes into account the turbine's tower height; for turbines rated at $20 \mathrm{~kW}$ or less, only those installed on towers of 100 feet or more qualify. The rebate amount varies based on the turbine type installed; whether the tower height is 100-119 feet, 120-139 feet, or 140 -159 feet; and the turbine's expected annual generation. ${ }^{56}$ For a Wisconsin residential consumer who considers installing a 20-kW Jacobs 31-20 turbine, Table 7 shows that the base incentive amount increases and the COE decreases when a taller tower is

\footnotetext{
${ }^{56}$ www.focusonenergy.com/files/Document_Management_System/Renewables/renewablereswind_applicationform. pdf. Accessed 5/5/2011.
} 
used. Many factors affect this outcome; the increased cost of the taller tower is offset by both the increased incentive amount and the increased generation resulting from the stronger winds.

Table 7 Wisconsin Focus on Energy Rebate Amounts for 20-kW Jacobs Turbine

\begin{tabular}{|l|c|c|}
\hline \multicolumn{1}{|c|}{ Turbine } & COE & Rebate Amount \\
\hline $\begin{array}{l}\text { 20-kW }-31-20 \text { Jacobs } \\
100-\mathrm{ft} \text { tower }\end{array}$ & $\$ 0.233$ & $\$ 7,193$ \\
\hline $\begin{array}{l}20-\mathrm{kW}-31-20 \text { Jacobs } \\
120-\mathrm{ft} \text { tower }\end{array}$ & $\$ 0.217$ & $\$ 8,678$ \\
\hline
\end{tabular}

\section{State Loan Scenario}

State loan programs for renewable energy systems are designed to provide loans at lower-thanmarket interest rates for the purchase and installation of equipment. Many of these programs are revolving loan funds, meaning that the loan money is recycled back into the program as it is paid back. Examples of states with renewable energy loan programs include Montana, Oregon, and Iowa.

Montana's Alternative Energy Revolving Loan Program, created in 2001, has an interest rate of $4 \%$ for 2011. These fixed-rate loans can be awarded for up to $\$ 40,000$ and can have a maximum term of 10 years. ${ }^{57}$ Oregon's State Energy Loan Program, financed through the sale of bonds, has awarded more than 840 loans to renewable energy projects since $1981 .^{58}$ There is no maximum loan amount, although they are typically $\$ 20,000$ to $\$ 20$ million, and the term (typically 5 to 15 years) cannot exceed the life of the project. ${ }^{59}$ The available rates vary depending on the availability of funds and the loan term but will be fixed for the life of the project. For commercial and residential loans, the current rates are $6 \%$ to $7.5 \% .^{60}$ Iowa's Alternative Energy Revolving Loan Program provides $50 \%$ of the total loan amount at $0 \%$ interest, with a maximum of $\$ 1$ million. The remainder of the loan amount is provided by another lender at the market rate. The maximum term for these loans is 20 years. ${ }^{61}$

To examine the impact a low- or no-interest state loan can have on the cost-effectiveness of distributed wind, a $20-\mathrm{kW}$ commercial-sector turbine (120-ft tower) in Iowa (mid Class 2 wind resource) is considered. Table 8 shows the base case, in which the turbine is purchased and installed with $100 \%$ equity, a state loan case, and a market-loan-only case. The state loan is Iowa's Alternative Energy Revolving Loan Program. The market loan is assumed to be a personal loan with an interest rate of $5 \%$, a rate assumed for the purpose of this case study. As Table 8 shows, the project economics are best when the state loan is utilized.

${ }_{58}^{57}$ www.deq.mt.gov/Energy/Renewable/altenergyloan.mcpx

${ }_{58}$ www.dsireusa.org/incentives/incentive.cfm?Incentive_Code $=$ OR04F\&re $=1 \&$ ee $=1$

${ }^{59}$ www.dsireusa.org/incentives/incentive.cfm?Incentive_Code=OR04F\&re=1\&ee $=1$

60 www.oregon.gov/ENERGY/LOANS/rates.shtml

61 www.dsireusa.org/incentives/incentive.cfm? Incentive_Code $=I A 06 F \& r e=1 \&$ ee $=1$ 
Table 8 lowa State Loan Scenario

\begin{tabular}{|l|c|c|c|c|c|}
\hline & $\begin{array}{c}\text { lowa Loan } \\
\text { Interest Rate }\end{array}$ & $\begin{array}{c}\text { Market } \\
\text { Interest Rate }\end{array}$ & $\begin{array}{c}\text { Final } \\
\text { Combined } \\
\text { Interest Rate }\end{array}$ & $\begin{array}{c}\text { Total } \\
\text { Loan } \\
\text { Amount }\end{array}$ & COE \\
\hline Base Case, 100\% Equity & $\mathrm{N} / \mathrm{A}$ & $\mathrm{N} / \mathrm{A}$ & $\mathrm{N} / \mathrm{A}$ & $\mathrm{N} / \mathrm{A}$ & $\$ 0.157$ \\
\hline With Market Loan Only & $\mathrm{N} / \mathrm{A}$ & $5 \%$ & $5 \%$ & $\$ 45,000$ & $\$ 0.12$ \\
\hline $\begin{array}{l}\text { With State Loan and } \\
\text { Market Loan }\end{array}$ & $0 \%$ & $5 \%$ & $2.5 \%$ & $\$ 45,000$ & $\$ 0.10$ \\
\hline
\end{tabular}

\section{Optimal Policy Combination}

The project team utilized the Policy Tool's underlying pro forma model to seek optimal combinations of policies that minimize the COE for distributed wind systems in Kansas, due to its limited number of incentives. The base case scenario for the commercial sector is a $100-\mathrm{kW}$ turbine on a 121-foot tower with no statewide net metering (valuing all wind generation at avoided cost), with $\$ 6,000$ interconnection costs, $\$ 2,500$ permitting costs, a Low Class 3 wind resource, and $\$ 0.001 / \mathrm{kWh}$ REC sales for 10 years.

Table 9 outlines the project economics for this base case scenario and shows how the economics change with each individual policy or incentive change. This example illustrates that adding a rebate alone would dramatically reduce the $\mathrm{COE}$ and upfront cost to customers; offsetting the onsite load (when $50 \%$ of wind generation is consumed "behind the meter" and valued at the retail rate as allowed by some state interconnection rules) and net metering improve the IRR and simple payback; and reducing permitting and interconnection costs have modest impacts. The $\$ 181,020$ rebate shown is the incentive the $100-\mathrm{kW}$ turbine would receive if New York's rebate program were available in Kansas, which when combined with the other improved policies as shown in Table 10 achieves favorable returns. 
Table 9 Kansas Base Case Scenario for Commercial-Sector 100-kW Turbine vs. Alternate Inputs

\begin{tabular}{|c|c|c|c|c|c|c|}
\hline & Base Case & $\begin{array}{c}\text { With } \\
\mathbf{\$ 1 8 1 , 0 2 0} \\
\text { Rebate }\end{array}$ & $\begin{array}{c}\text { With Offset } \\
\text { of Onsite } \\
\text { Load }\end{array}$ & $\begin{array}{c}\text { With } \\
\text { Statewide } \\
\text { Net } \\
\text { Metering }\end{array}$ & $\begin{array}{c}\text { With } \$ 0 \\
\text { Interconnection } \\
\text { Cost }\end{array}$ & $\begin{array}{c}\text { With } \$ 0 \\
\text { Permitting } \\
\text { Cost }\end{array}$ \\
\hline COE & $\$ 0.128$ & $\$ 0.085$ & $\$ 0.128$ & $\$ 0.128$ & $\$ 0.126$ & $\$ 0.127$ \\
\hline NPV & $(\$ 239,364)$ & $(\$ 122,184)$ & $(\$ 175,955)$ & $(\$ 112,546)$ & $(\$ 233,364)$ & $(\$ 236,864)$ \\
\hline IRR & $-5 \%$ & $-1 \%$ & $-1 \%$ & $3 \%$ & $-5 \%$ & $-5 \%$ \\
\hline $\begin{array}{c}\text { Simple } \\
\text { Payback } \\
\text { (Years) }\end{array}$ & $\begin{array}{c}\text { More than } \\
20\end{array}$ & $\begin{array}{c}\text { More than } \\
20\end{array}$ & $\begin{array}{c}\text { More than } \\
20\end{array}$ & 16 & $\begin{array}{c}\text { More than } \\
20\end{array}$ & $\begin{array}{c}\text { More than } \\
20\end{array}$ \\
\hline
\end{tabular}

When the policy and incentives are changed simultaneously and combined, the result is a highly cost-effective project. Table 10 shows that the COE is reduced by $75 \%$ when the optimized scenario is compared to the base case. IOUs in Kansas already offer net metering, so this example highlights the benefits of adding a rebate and extending net metering to rural electric cooperatives and public utilities.

Table 10 Kansas Base Case Scenario for Commercial-Sector 100-kW Turbine vs. Optimized Policy Combination

\begin{tabular}{|c|c|c|}
\hline & Base Case & $\begin{array}{c}\text { With \$181,020 Rebate, } \\
\text { Statewide Net Metering, }\end{array}$ \\
\hline COE & $\$ 0.128$ & $\$ 0.081$ \\
\hline NPV & $(\$ 239,364)$ & $\$ 13,134$ \\
\hline IRR & $-5 \%$ & $8 \%$ \\
\hline $\begin{array}{c}\text { Simple Payback } \\
\text { (Years) }\end{array}$ & More than 20 & 9 \\
\hline
\end{tabular}




\section{Accomplishments}

The Distributed Wind Policy Comparison Tool web-based dashboard provides utilities, policymakers, and advocates with a user-friendly means to quantify the financial impacts of distributed wind policy development. When weighing the pros and cons of available policy options, it is important to consider several questions:

- How do federal, state, and local policies affect and interact with each other?

- How can renewable production (kWh) be best incentivized?

- What attractive financial policies for distributed wind are the easiest to implement from an administrative standpoint?

- What funding sources are available to pay for distributed wind policy enhancements?

- Are there economic tradeoffs that need to be made in order to implement a particular policy?

- In an ideal world, how often should existing policies be revisited and/or updated?

- Which policies are the most popular among industry groups and installers?

- What is the overall goal (e.g., facilitate administrative processes, stimulate market growth in the industry, increase the number of installations or amount of installed capacity), and which policies most readily affect that goal?

The case studies explored demonstrate how the Policy Tool can provide insight into "what if" scenarios and allow close examination of the current status of incentives. Policymakers frequently adjust and update polices and incentives. The Policy Tool can be used to gauge how those changes impact the economics of distributed wind, and subsequently its market growth. It can also allow policymakers to determine the effectiveness of individual incentive programs, thereby addressing market challenges identified in the DOE's " $20 \%$ Wind Energy by 2030 " report.

The project's final products include:

- Distributed Wind Policy Tool: www.windpolicytool.org

- Distributed Wind Policy Tool Guidebook: User Instructions, Assumptions and Case Studies

- Distributed Wind Policy Tool Guidebook: User Instructions

- Policy and Market Trends: Improving Small Wind's Bottom Line, poster presented at AWEA WINDPOWER 2011, Anaheim, California

- Small Wind Policy Comparison Tool: An ASES Small Wind Division Webinar, http://www.windpoweringamerica.gov/filter_detail.asp?itemid=3198

\section{Conclusions}

In providing a simple and easy-to-use policy comparison tool that estimates financial performance, the Policy Tool and guidebook are expected to enhance market expansion by the small wind industry by increasing and refining the understanding of distributed wind costs, policy best practices, and key market opportunities in all 50 states. This comprehensive overview and customized software to quickly calculate and compare policy scenarios represent a 
fundamental step in allowing policymakers to see how their decisions impact the bottom line for distributed wind consumers, while estimating the relative advantages of different options available in their policy toolboxes.

\section{Recommendations}

Interested stakeholders have suggested numerous ways to enhance and expand the initial effort to develop an even more user-friendly Policy Tool and guidebook, including:

\section{Enhancements and Outreach for Current Tool}

- Allow users to manually adjust annual estimated production to allow review of additional turbine options, wind resources, wind shear assumptions, and other variables

- Incorporate a user-friendly interactive national web display of wind map data (at hub heights typical for distributed wind applications) to allow more nuanced analysis

- Create user-friendly interactive national Web display of all distributed wind incentives and resulting financial metrics

- Enable automatic updates of the Policy Tool with dynamic interfaces and underlying databases including DSIRE, SWCC power curves, and utility rates, among others

- Conduct additional webinars targeting specific states or regions, tailored to additional specific stakeholders such as rural electric utilities, state legislators, county planning officials, and extension agents

- Produce a video instructional guide on how to use the Policy Tool

- Ensure ongoing maintenance and regular updates of the Policy Tool, including wind turbine pricing estimates and other key default assumptions.

\section{Expansion of Tool}

- Add additional turbine and tower options, especially taller tower options, and at least one vertical-axis design. Expand the Policy Tool's capacity to cover mid-size distributed wind turbines (up to $300 \mathrm{~kW}-1 \mathrm{MW}$ )

- Expand the Policy Tool into a more comprehensive project evaluation Toolkit, including costs for environmental evaluations and other make-or-break factors

- Enable macro analysis of cumulative impacts on electricity rates such as from a high penetration of net metering applications within specific utility service areas and/or high uptake level for incentives in local jurisdictions

- Build out the DSIRE database with more utility-specific net metering agreements and rate schedules applicable to distributed wind; county-specific local zoning ordinances, including fees and estimates of costs for required inspections and insurance; permitting guidelines and studies required; and other policy details, such as estimated REC values

- Enable review of more complex financing scenarios, such as a Minnesota Flip ${ }^{62}$ style public/private structure to help government agencies and non-profits justify investments in

\footnotetext{
${ }^{62}$ www.windustry.org/minnesota-flip
} 
distributed wind projects. Allow review of multi-turbine "commercial stage" projects and "neighborhood" or community net metering ${ }^{63}$ applicable to joint-ownership of a project

- Create an option in the model that factors in the probability of success for grants that are not guaranteed, discounting the project's total cost/present value accordingly. Likewise, certain loans carry requirements making them slightly more competitive than first-come, first-served rebate awards, which may be worth considering

- Incorporate additional review of height restrictions, zoning, and interconnection issues to capture the value of risk at decision points and enable more accurate quantitative market comparisons. Permitting and environmental reviews generally entail at-risk expenses, paid whether or not the project is approved. Little data is available on the difficulty of permitting across the country, so a real options analysis ${ }^{64}$ comparing and extrapolating from a few representative jurisdictions may be informative.

\section{Further Analysis}

- Enable a more nuanced view of net metering and load/generation profile overlap. Pricing all production at avoided cost for states without net-metering policies in place for all utilities may result in an overly conservative analysis. Load profiles by customer sector can often be obtained directly from utilities, and daily and seasonal wind profiles can be computed from ASOS data sets for areas of interest.

- Create case studies on real world turbine installations; show actual costs and incentives received for turbines in a few states. Include real-time data on turbine production to show power curves and COE.

- Evaluate case studies to optimize a leasing scenario addressing the desire by commercial entities to avoid cash flow impacts of direct purchases and balance sheet impacts of financing, which reduce their net borrowing capacity. Many companies use a high hurdle rate for capital investments, often higher for investments that are not central to their core business. Projects structured as an operating lease have low to no balance sheet impact. Companies might accept lower rates of return on such a lease option to be able to support visible green power.

- Conduct further analysis on the long-term nature and price stability of RECs, typically only priced out 5 to 10 years, and educate policymakers on the difference between distributed energy carve-outs versus solar-only policies.

- Contrast the Policy Tool's state ranking results with sales data, and use the Policy Tool to estimate the total value of state, utility, and federal incentives.

While the primary audience for the initial Policy Tool and Guidebook is state-level policymakers, these suggestions could effectively expand the project's value for suppliers, endusers, and other industry stakeholders and further assist DOE in reaching COE targets for distributed wind.

${ }_{64}^{63} \mathrm{http} / / /$ sites.google.com/site/massdgic/Home/net-metering-in-ma

${ }^{64} \underline{\mathrm{http}}$ ://ardent.mit.edu/real_options/Real_opts_papers/Dykes_\%20WWEC\%202008_Final_Oct08.pdf 


\section{References}

American Wind Energy Association. Policies to Promote Small Wind Turbines - A Policy Menu for State and Local Governments.

www.awea.org/learnabout/smallwind/upload/Policies_to_Promote_Small_Wind_Turbines.pdf

American Wind Energy Association. (2008). In the Public Interest: How and Why to Permit for Small Wind Systems. www.awea.org/learnabout/smallwind/upload/InThePublicInterest.pdf

Bolinger, M. (2010). Revealing the Hidden Value that the Federal Investment Tax Credit and Treasury Cash Grant Provide To Community Wind Projects. http://eetd.lbl.gov/ea/ems/reports/lbnl-2909e.pdf

Cory, K., T. Couture, and C. Kreycik. (2009). Feed-In Tariff Policy: Design, Implementation, and RPS Policy Interactions. www.nrel.gov/docs/fy09osti/45549.pdf

Edwards, J., R. Wiser and M. Bolinger. (2004). Evaluating State Markets for Residential Wind Systems: Results from an Economic and Policy Analysis Tool.

http://eetd.lbl.gov/ea/emp/reports/56344.pdf

Edwards, J., R. Wiser, M. Bolinger, and T. Forsyth. (2004). Building a Market for Small Wind: The Break-Even Turnkey Cost of Renewable Wind Systems in the United States. Presented at Global Windpower, Chicago, IL. http://eetd.lbl.gov/ea/emp/reports/54865.pdf

Forsyth, T., H. Rhoads-Weaver. (2009). Current and Past DWT Policy. Presentation at Windpower 2009. Chicago, IL.

www.eformativeoptions.com/docs/DWT_Policy_Windpower_2009.pdf

Forsyth, T., P. Tu, and J. Gilbert (2000). Economics of Grid-Connected Small Wind Turbines in the Domestic Market. National Renewable Energy Laboratory, Golden CO. NREL Report No. CP-500-26975. www.nrel.gov/docs/fy00osti/26975.pdf

Gifford, J., R. Grace. (2011). Sustainable Energy Advantage, LLC. CREST Cost of Renewable Energy Spreadsheet Tool: A Model for Developing Cost-Based Incentives in the United States. User Manual Version 1. www.nrel.gov/docs/fy11osti/50374.pdf

Jimenez, Tony. (2010). Managing Expectations: Estimating Small Wind Turbine Energy Output and Economic Performance.

www.windpoweringamerica.gov/media/2010/webinar_ases_small_wind_expectations.wmv

Kubert, C., and M. Sinclair. Clean Energy States Alliance. (2010). State-Based Financing Tools to Support Distributed and Community Wind Projects.

www.cleanenergystates.org/assets/Uploads/Resources-pre-8-16/CESA-state-financing-toolswind2010.pdf

Kubert, C., and M. Sinclair. Clean Energy States Alliance. (2010). Supporting On-Site

Distributed Wind Generation Projects. www.cleanenergystates.org/resource-

library/resource/supporting-on-site-distributed-wind-generation-projects 
Kwartin, R., A. Wolfrum, K. Granfield, A. Kagel, and A. Appleton. (2008). An Analysis of the Technical and Economic Potential for Mid-Scale Distributed Wind. NREL/SR-500-44820. ICF International, Fairfax, VA. www.nrel.gov/wind/pdfs/midscale_analysis.pdf

Interstate Renewable Energy Council. (2009). Model Interconnection Procedures 2009 Edition. www.irecusa.org/wp-content/uploads/2010/01/IREC-Interconnection-Procedures-2010final.pdf

Interstate Renewable Energy Council. (2009). Model Net Metering Rules 2009 Edition. $\underline{\text { www.irecusa.org/NMmodel09 }}$

National Renewable Energy Laboratory Wind Energy Finance Tool. http://analysis.nrel.gov/windfinance/login.asp

National Renewable Energy Laboratory, Figure of Merit - Cost of Energy documentation (personal communication Karin Sinclair).

Network for New Energy Choices (2009). Freeing the Grid.

www.newenergychoices.org/uploads/FreeingTheGrid2009.pdf

Network for New Energy Choices (2010). Freeing the Grid.

www.newenergychoices.org/uploads/FreeingTheGrid2010.pdf

Orrell, A., B. Antonich. (2007). Windustry Wind Project Calculator.

www.windustry.org/sites/windustry.org/files/WindProjectCalculator-091007.xls

Pitt, Damian. (2008). How to Overcome Permitting Obstacles to Small-Scale Distributed Renewable Energy. Prepared for Network for New Energy Choices.

www.newenergychoices.org/uploads/redTape-rep.pdf

United States Department of Energy. Energy Efficiency and Renewable Energy. 20\% Wind Energy by 2030: Increasing Wind Energy's Contribution to U.S. Electricity Supply.

www.nrel.gov/docs/fy08osti/41869.pdf

Vanega, Amanda. (2010). Introduction to DSIRE for the Small Wind Community. ASES Small Wind Webinar. www.dsireusa.org/library/index.cfm?ee $=1 \& \mathrm{RE}=1$

Wind Powering America Small Wind Economic Model.

www.windpoweringamerica.gov/docs/small_wind_economic_model.xls 


\section{Appendix A Wind Turbines and Related Information Included in Policy Tool}

Note: Pricing in Table 11 is as of mid-2011. Prices and incentives used in this report may not reflect current market values.

Table 11 Wind Turbine Technical Information

\begin{tabular}{|c|c|c|c|c|c|c|}
\hline Manufacturer & $\begin{array}{l}\text { Southwest } \\
\text { Wind Power }\end{array}$ & $\begin{array}{l}\text { Southwest } \\
\text { Wind Power }\end{array}$ & Endurance & $\begin{array}{l}\text { Proven } \\
\text { Energy }\end{array}$ & XZERES & XZERES \\
\hline Turbine Model & $\begin{array}{c}\text { Skystream } \\
3.7 \\
\end{array}$ & Skystream 3.7 & S-343 & P11 & ARE442 & ARE442 \\
\hline Nameplate Capacity (kW) & 2.4 & 2.4 & 5 & 6 & 10 & 10 \\
\hline Hub Height (m) & 14.7 & 21.3 & 31.1 & 15 & 18.3 & 30.5 \\
\hline Rotor Diameter (m) & 3.7 & 3.7 & 6.37 & 5.48 & 7.2 & 7.2 \\
\hline Number of Blades & 3 & 3 & 3 & 3 & 3 & 3 \\
\hline Tower Type & Monopole & Guyed & Guyed & $\begin{array}{c}\text { Tilt-up } \\
\text { monopole }\end{array}$ & Lattice & Lattice \\
\hline Power Curve Source & NREL tested & NREL tested & Endurance & $\begin{array}{l}\text { Proven } \\
\text { Energy }\end{array}$ & $\begin{array}{c}\text { NREL } \\
\text { tested }\end{array}$ & $\begin{array}{c}\text { NREL } \\
\text { tested }\end{array}$ \\
\hline Cut-in Wind Speed (m/s) & 3.5 & 3.5 & 4.1 & 3.5 & 2.2 & 2.2 \\
\hline $\begin{array}{l}\text { Annual Production - Class } 2 \\
\text { Wind Resource }(\mathbf{k W h})^{* *}\end{array}$ & 2,349 & 2,983 & 8,418 & 5,429 & 10,748 & 14,397 \\
\hline Installation Cost & $\$ 16,900$ & $\$ 17,200$ & $\$ 48,000$ & $\$ 49,000$ & $\$ 60,000$ & $\$ 80,000$ \\
\hline Interconnection Cost $* * *$ & $\$ 300$ & $\$ 300$ & $\$ 300$ & $\$ 300$ & $\$ 300$ & $\$ 300$ \\
\hline Permitting Cost $* * *$ & $\$ 300$ & $\$ 500$ & $\$ 500$ & $\$ 500$ & $\$ 500$ & $\$ 800$ \\
\hline Total Installed Cost & $\$ 17,500$ & $\$ 18,000$ & $\$ 48,800$ & $\$ 49,800$ & $\$ 60,800$ & $\$ 81,100$ \\
\hline
\end{tabular}

*Manufacturer-provided curves typically have higher values than output measured by NREL.

**Based on low Class 2 wind speeds and supplied power curves. Energy production values given in the table may vary from those used in the guidebook's case studies because updated power curves were provided by some manufacturers.

***Interconnection and permitting costs are assumed. 
Table 11 (continued) Wind Turbine Technical Information

\begin{tabular}{|c|c|c|c|c|c|}
\hline Manufacturer & Bergey & Bergey & Gaia & $\begin{array}{c}\text { Wind Turbine } \\
\text { Industries } \\
\text { Corp. }\end{array}$ & $\begin{array}{c}\text { Wind Turbine } \\
\text { Industries } \\
\text { Corp. }\end{array}$ \\
\hline Turbine Model & BWC EXCEL & BWC EXCEL & G11 & 31-20 Jacobs & 31-20 Jacobs \\
\hline $\begin{array}{l}\text { Nameplate } \\
\text { Capacity (kW) }\end{array}$ & 10 & 10 & 11 & 20 & 20 \\
\hline Hub Height (m) & 30.5 & 36.6 & 18 & 30.5 & 36.6 \\
\hline $\begin{array}{l}\text { Rotor Diameter } \\
(\mathrm{m})\end{array}$ & 7 & 7 & 13 & 9.45 & 9.45 \\
\hline $\begin{array}{l}\text { Number of } \\
\text { Blades }\end{array}$ & 3 & 3 & 3 & 3 & 3 \\
\hline Tower Type & Guyed Lattice & $\begin{array}{c}\text { Freestanding } \\
\text { Lattice }\end{array}$ & $\begin{array}{c}\text { Freestanding } \\
\text { Lattice }\end{array}$ & $\begin{array}{c}\text { Freestanding } \\
\text { Lattice }\end{array}$ & $\begin{array}{c}\text { Freestanding } \\
\text { Lattice }\end{array}$ \\
\hline $\begin{array}{l}\text { Power Curve } \\
\text { Source }\end{array}$ & Bergey & Bergey & Gaia & WTIC & WTIC \\
\hline $\begin{array}{l}\text { Cut-in Wind } \\
\text { Speed }(\mathrm{m} / \mathrm{s})\end{array}$ & 2.5 & 2.5 & 3.5 & 3.6 & 3.6 \\
\hline $\begin{array}{l}\text { Annual } \\
\text { Production - } \\
\text { Class } 2 \text { Wind } \\
\text { Resource } \\
(\mathrm{kWh}) * *\end{array}$ & 12,985 & 14,319 & 32,367 & 23,489 & 25,810 \\
\hline Installation Cost & $\$ 58,900^{1}$ & $\$ 83,900^{2}$ & $\$ 130,000$ & $\$ 87,000$ & $\$ 90,000$ \\
\hline $\begin{array}{l}\text { Interconnection } \\
\text { Cost*** }\end{array}$ & $\$ 300$ & $\$ 300$ & $\$ 700$ & $\$ 700$ & $\$ 700$ \\
\hline $\begin{array}{l}\text { Permitting } \\
\text { Cost*** }\end{array}$ & $\$ 800$ & $\$ 800$ & $\$ 500$ & $\$ 800$ & $\$ 800$ \\
\hline $\begin{array}{l}\text { Total Installed } \\
\text { Cost }\end{array}$ & $\$ 60,000$ & $\$ 85,000$ & $\$ 131,200^{3}$ & $\$ 88,500$ & $\$ 91,500$ \\
\hline
\end{tabular}

*Manufacturer-provided curves typically have higher values than output measured by NREL.

**Based on low Class 2 wind speeds and supplied power curves. Energy production values given in the table may vary from those used in the guidebook's case studies because updated power curves were provided by some manufacturers.

*** Interconnection and permitting costs are assumed.

${ }^{1}$ Table reflects current pricing; 2010 values of $\$ 56,000$ installation cost and $\$ 57,100$ total installed cost were used in the guidebook's case studies.

${ }^{2}$ Table reflects current pricing; 2010 values of $\$ 73,600$ installation cost and $\$ 74,700$ total installed cost were used in the guidebook's case studies.

${ }^{3}$ Table reflects current pricing; 2010 values of $\$ 65,000$ installation cost and $\$ 66,200$ total installed cost for an $18-\mathrm{m}$ tower were used in the guidebook's case studies. 
Table 11 (continued) Wind Turbine Technical Information

\begin{tabular}{|l|c|c|c|}
\hline Manufacturer & Endurance & Endurance & $\begin{array}{c}\text { Northern } \\
\text { Power }\end{array}$ \\
\hline Turbine Model & E3120 & E3120 & $\begin{array}{c}\text { Northwind } \\
100\end{array}$ \\
\hline Nameplate Capacity (kW) & 50 & 50 & 100 \\
\hline Hub Height (m) & 36.4 & 43.7 & 37 \\
\hline Rotor Diameter (m) & 19.2 & 19.2 & 21 \\
\hline Number of Blades & 3 & 3 & 3 \\
\hline Tower Type & Monopole & Lattice & Monopole \\
\hline Power Curve Source & Endurance & Endurance & $\begin{array}{c}\text { Northern } \\
\text { Power }\end{array}$ \\
\hline Cut-in Wind Speed (m/s) & 3.5 & 3.5 & 3.1 \\
\hline $\begin{array}{l}\text { Annual Production - Class } \\
\text { 2 Wind Resource (kWh)** }\end{array}$ & 116,195 & 125,293 & 169,892 \\
\hline Installation Cost & $\$ 381,500^{4}$ & $\$ 346,500^{5}$ & $\$ 541,500$ \\
\hline Interconnection Cost*** & $\$ 1,500$ & $\$ 1,500$ & $\$ 6,000$ \\
\hline Permitting Cost*** & $\$ 2,000$ & $\$ 2,500$ & $\$ 2,500$ \\
\hline Total Installed Cost & $\$ 385,000^{4}$ & $\$ 350,500^{5}$ & $\$ 550,000$ \\
\hline
\end{tabular}

*Manufacturer-provided curves typically have higher values than output measured by NREL.

**Based on low Class 2 wind speeds and supplied power curves.

***Interconnection and permitting costs are assumed.

${ }^{4}$ Table reflects current pricing; 2010 values of $\$ 345,000$ installation cost and $\$ 348,500$ total installed cost were used in the guidebook's case studies.

${ }^{5}$ Table reflects current pricing; 2010 values of $\$ 310,000$ installation cost and $\$ 314,000$ total installed cost were used in the guidebook's case studies. 


\section{Appendix B Retail Electricity Prices by State}

Table 12 Average Retail Price of Electricity, January 2011 and 2010 (Cents per kWh) ${ }^{65}$

\begin{tabular}{|c|c|c|c|c|}
\hline & \multicolumn{2}{|c|}{ Residential } & \multicolumn{2}{|c|}{ Commercial } \\
\hline Census Division \& State & 2011 & 2010 & 2011 & 2010 \\
\hline Alabama & 10.44 & 10.02 & 10.31 & 10.07 \\
\hline Alaska & 16.61 & 16.01 & 14.69 & 13.4 \\
\hline Arizona & 9.84 & 9.58 & 8.6 & 8.43 \\
\hline Arkansas & 7.77 & 8.42 & 6.84 & 7.59 \\
\hline California & 15.3 & 15.69 & 12.26 & 12.18 \\
\hline Colorado & 10.4 & 10.3 & 8.31 & 8.13 \\
\hline Connecticut & 18.03 & 19.14 & 16.02 & 16.54 \\
\hline Delaware & 13 & 12.68 & 10.99 & 11.29 \\
\hline District of Columbia & 13.62 & 13.29 & 13.18 & 13.19 \\
\hline Florida & 11.57 & 9.48 & 9.96 & 7.59 \\
\hline Georgia & 9.8 & 9.12 & 9.68 & 8.9 \\
\hline Hawaii & 30.13 & 26.71 & 28 & 24.73 \\
\hline Idaho & 7.83 & 7.75 & 6.45 & 6.54 \\
\hline Illinois & 10.41 & 9.93 & 8.08 & 8.49 \\
\hline Indiana & 9.35 & 8.48 & 8.55 & 7.98 \\
\hline Iowa & 9.45 & 8.67 & 7.29 & 6.9 \\
\hline Kansas & 9.35 & 8.61 & 7.94 & 7.3 \\
\hline Kentucky & 8.65 & 7.75 & 7.96 & 7.18 \\
\hline Louisiana & 7.94 & 8.11 & 7.99 & 8.11 \\
\hline Maine & 15.78 & 15.44 & 13.16 & 12.9 \\
\hline Maryland & 13.39 & 14.16 & 11.62 & 11.59 \\
\hline Massachusetts & 14.8 & 15.56 & 14.35 & 14.47 \\
\hline Michigan & 12.16 & 11.41 & 9.62 & 9.41 \\
\hline Minnesota & 10.35 & 9.51 & 8.08 & 7.62 \\
\hline Mississippi & 9.71 & 9.01 & 9.64 & 9.06 \\
\hline Missouri & 8.16 & 7.17 & 6.93 & 6.15 \\
\hline Montana & 9.08 & 8.45 & 8.74 & 7.98 \\
\hline Nebraska & 7.72 & 7.22 & 7.32 & 6.86 \\
\hline Nevada & 11.61 & 12.05 & 9.17 & 9.92 \\
\hline New Hampshire & 16.34 & 15.79 & 14.31 & 14.18 \\
\hline New Jersey & 16.14 & 15.88 & 13.29 & 14.01 \\
\hline New Mexico & 9.77 & 9.65 & 8.21 & 8.09 \\
\hline New York & 17.4 & 17.08 & 15.59 & 15.22 \\
\hline North Carolina & 9.48 & 9.49 & 7.75 & 7.9 \\
\hline North Dakota & 6.92 & 6.81 & 6.59 & 6.35 \\
\hline Ohio & 10.13 & 10.24 & 9.32 & 9.56 \\
\hline Oklahoma & 8.06 & 7.54 & 7.11 & 6.82 \\
\hline Oregon & 9.19 & 8.35 & 7.97 & 7.35 \\
\hline Pennsylvania & 12.62 & 11.72 & 9.82 & 9.77 \\
\hline Rhode Island & 16.21 & 15.42 & 13.25 & 13.51 \\
\hline South Carolina & 10.23 & 10.07 & 9.12 & 8.81 \\
\hline South Dakota & 8.24 & 7.72 & 7.29 & 6.88 \\
\hline Tennessee & 9.49 & 8.19 & 10 & 8.74 \\
\hline Texas & 10.96 & 11.27 & 8.85 & 9.31 \\
\hline Utah & 8.17 & 8.07 & 6.56 & 6.41 \\
\hline Vermont & 15.79 & 14.77 & 13.75 & 12.99 \\
\hline Virginia & 9.64 & 10.01 & 7.51 & 7.76 \\
\hline Washington & 8.02 & 7.63 & 7.47 & 7.13 \\
\hline West Virginia & 8.78 & 8.19 & 7.75 & 7.25 \\
\hline Wisconsin & 12.4 & 11.86 & 10.11 & 9.55 \\
\hline Wyoming & 8.33 & 8.03 & 7.28 & 7.1 \\
\hline U.S. Total & 10.99 & 10.56 & 9.88 & 9.63 \\
\hline
\end{tabular}

\footnotetext{
${ }^{65}$ Some utilities charge customers increasing block rates, such as Southern California Edison's $\$ 0.16-\$ 0.38 / \mathrm{kWh}$ for residential customers, in which wind generation saves the most expensive electricity first.
} 


\section{Appendix C Sensitivity Analyses}

The project team conducted several sensitivity analyses on factors that are external to the decision making process. In other words, the analyses reviewed factors that are largely outside the control of policymakers or project developers but could still impact project economics. These factors include the assumed discount rate, escalation rate, and project life.

\section{Discount Rate}

Selecting discount rates for a pro forma financial analysis can be a contentious issue. Discount rates can have a significant impact on a project's NPV. For the Policy Tool, the project team selected conservative rates, as described in the Assumptions section. To test these discount rate assumptions, a sensitivity analysis of the discount rates was performed across all states and sectors. In general, it was found that varying the discount rate did not have a strong impact on project economics. For example, reducing the discount rate to 4 percentage points below the base case rate did not provide a positive NPV for more than $90 \%$ of the negative-NPV base case scenarios.

For a project in a state with strong incentives (e.g., Oregon), even a large change in the discount rate is not enough to change the project from having a positive NPV to a negative NPV. Alternately, a significant change in discount rates is not enough to give a project in Tennessee, which is at the bottom of the state rankings, a positive NPV. Table 13 shows these results.

Table 13 NPV of a Residential 2.4-kW System with Varying Discount Rates for Oregon and Tennessee

\begin{tabular}{|l|c|c|c|}
\hline & \% Discount Rate & $\begin{array}{c}\text { 6\% Discount Rate } \\
\text { (Default Setting) }\end{array}$ & 10\% Discount Rate \\
\hline Oregon & $\$ 4,802$ & $\$ 1,618$ & $\$ 363$ \\
\hline Tennessee & $(\$ 12,366)$ & $(\$ 13,418)$ & $(\$ 13,850)$ \\
\hline
\end{tabular}

\section{Escalation Rate}

Selecting escalation rates for pro forma financial analysis can also be a contentious issue. The COE of a wind energy system compares favorably to retail electricity prices that are escalating at a high rate, but a pro forma model cannot simply include high escalation rates just to improve project economics.

In the Policy Tool, a conservative cost escalation index rate is applied to O\&M costs and electricity prices. Electricity prices are also multiplied by an electricity price escalation index rate. In general, as electricity prices increase, project economics improve. States with statewide net metering and/or high electricity prices see the most impact from an increased electricity price escalation rate as the assumption is that net metering is valued at the state's retail electric rate. 


\section{Project Life}

For the final sensitivity analysis, the project team adjusted the project life from 20 to 15 years and 20 years to 25 years to see how the project life assumption impacts project economics.

This analysis shows that IRR improvement is in direct correlation to the length of the project at a relatively consistent rate. This improvement remains consistent across all four project scenarios $(2.4 \mathrm{~kW}, 10 \mathrm{~kW}, 50 \mathrm{~kW}$, and $100 \mathrm{~kW})$. Figure 7 shows the average IRR across all 50 states, for each of four project scenarios.

Commercial projects are impacted less than residential and non-taxed sector projects. This outcome makes sense when considering that commercial projects typically experience a shorter payback time due to depreciation and other tax incentives not available to the residential and non-taxed sectors. In other words, most commercial projects recoup their initial costs before the 15-year mark, so shortening the lifespan from 20 to 15 years does not affect those as much as it does residential projects.

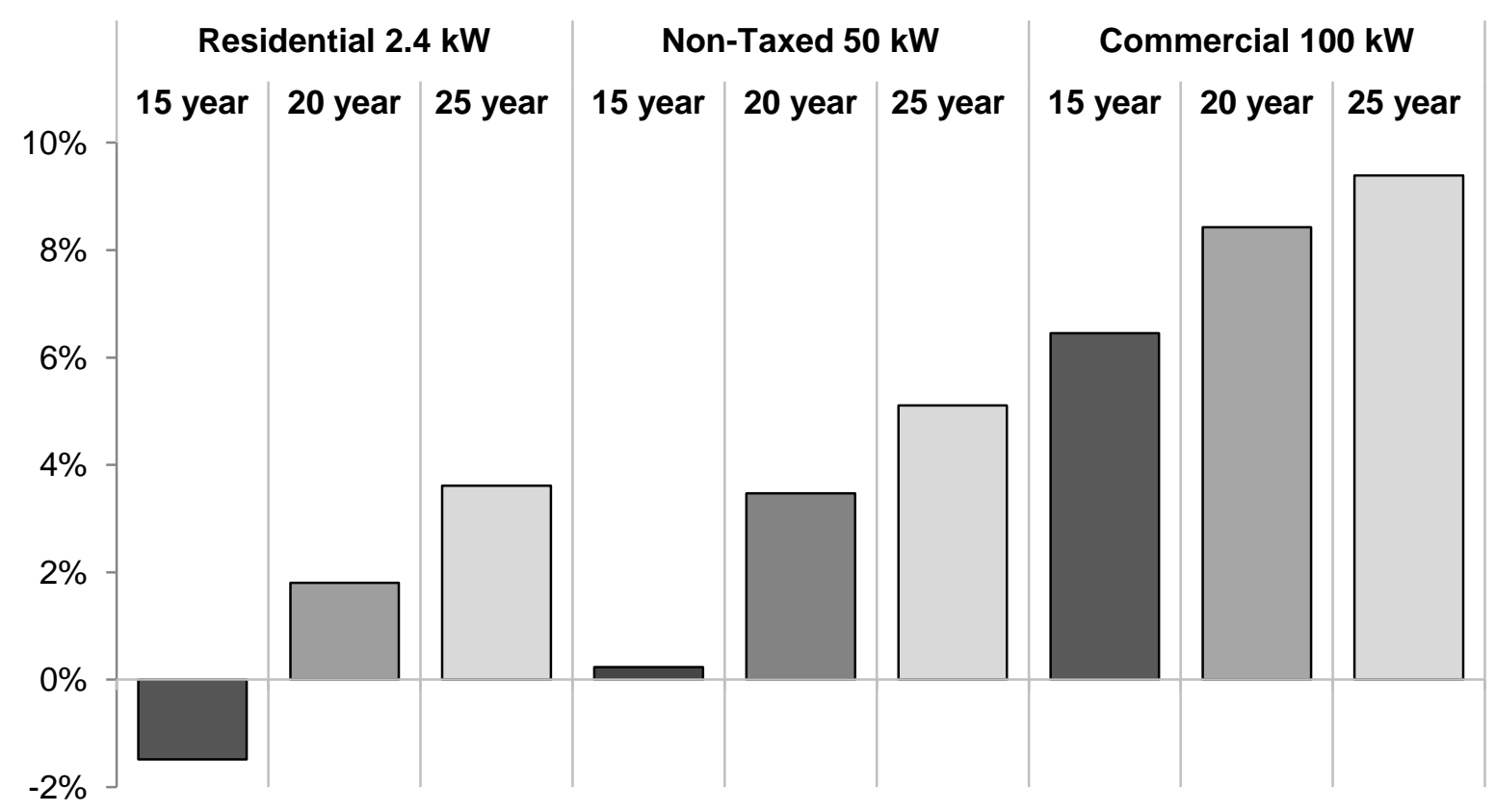

Figure 7 Average impact on IRR for top 10 states with 15-, 20-, and 25-year project lifespans 


\section{Appendix D Definitions}

The following terms will assist in understanding the Policy Tool's inputs and policies. Many of the following definitions were adapted from Windustry's Wind Energy Glossary and the DSIRE Glossary. $^{66}$

Avoided cost: The rate that utilities are required to pay independent power producers according to the Public Utilities Regulatory Policy Act. Avoided cost is simply the cost that the utility would have incurred for producing the same amount of power. This rate is estimated to average $41 \%$ of the utility's retail rate across the country.

Cost of energy (COE): The net present value of the total life cycle costs of a project divided by the total quantity of energy $(\mathrm{kWh})$ produced over the life of the project.

Commercial (sector): For purposes of this project, a project owned by a commercial entity that pays business taxes and uses the energy to support its business operations. Wind turbines in the commercial sector cover a wide range; the Policy Tool default selection is $100 \mathrm{~kW}$.

Debt vs. equity: Debt and equity are the two main sources of capital available to businesses, and each offers advantages and disadvantages. Debt financing takes the form of loans that must be repaid over time, usually with interest. Equity financing takes the form of money obtained from investors in exchange for an ownership share in the business. ${ }^{67}$

Depreciation: An accounting method used to attribute the cost of an asset over the span of its useful life. The cost, or a portion thereof, can be assigned as a loss on the project's balance sheet to reduce the tax base of the project. ${ }^{68}$

Discount rate: Used to convert forecasted cash flows into present value cash flows. The discount rate captures the time value of money. A dollar today is worth more than a dollar 20 years from now because money can be earned on today's dollar by investing it. The discount rate measures how much more today's dollar is worth. ${ }^{69}$

Distributed wind: The use of smaller wind turbines at homes, farms, businesses, and public facilities to offset all or a portion of on-site energy consumption, also commonly referred to as small and community wind. The upper range considered for purposes of this project is $100 \mathrm{~kW}$.

Feed-in tariff (FIT): An energy-supply policy focused on supporting the development of new renewable power generation. In the United States, FIT policies may require utilities to purchase electricity or both electricity and the renewable energy attributes from eligible renewable energy generators. The FIT contract provides a guarantee of payments in dollars per kilowatt hour

\footnotetext{
${ }_{67}^{66}$ ww.windustry.org/glossary and www.dsireusa.org/glossary

67 www.enotes.com/management-encyclopedia

68 www.investopedia.com

${ }^{69}$ Orrell, AC. 2007. Financial Jargon for New Entrants. Poster for American Wind Energy Association WINDPOWER 2007 Conference \& Exhibition.
} 
$(\$ / \mathrm{kWh})$ for the full output of the system for a guaranteed period of time (typically 15 to 20 years). A separate meter is required to track the actual total system output. ${ }^{70}$

Height: Permitting regulations often refer to the maximum total height of a wind turbine allowed. Typically, taller towers more efficiently capture available wind resources. Total height is the hub height plus the rotor radius.

Hub height: The height of the tower where a wind energy conversion system is mounted, measured from the ground.

Installation costs: All the expenses required to construct and get a turbine up and running, including but not limited to foundation construction, laying of electrical wire, crane, labor, and other associated costs.

Interconnection: The process of connecting an electrical generator to the electrical power grid or the physical location of the connection of an electrical generator to the electrical power grid. An Interconnection Standard includes the technical requirements and the legal procedures whereby a customer-sited generator interfaces with the electricity grid. ${ }^{71}$

Internal rate of return (IRR): A measure of profitability that tells users the size of return, as a percentage, to expect on an investment based on the cash flows of the project. The IRR rule is to accept an investment project if the opportunity cost of capital (the discount rate) is less than the IRR. Formally defined, the IRR is the discount rate at which the net present value (NPV) equals zero. If the discount rate is less than the IRR, the project has a positive NPV. If the discount rate is greater than the IRR, the project has a negative NPV. ${ }^{72}$

Investment Tax Credit (ITC): A policy that allows the party investing in a qualifying project to receive a tax credit for a set percentage of their investment. This is in contrast to a Production Tax Credit (PTC) in which a pre-defined tax credit calculated per kWh generated by the project is provided for a set number of years. ${ }^{73}$

Kilowatt (kW): The basic unit of electric demand, equal to 1,000 Watts.

Kilowatt-hour (kWh): A unit of energy equal to 1,000 Watt-hours. The basic measure of electric energy generation or use. A 100-Watt light bulb that is left on for 10 hours uses one $\mathrm{kWh}^{74}$

Loss: The estimated energy loss of the estimated gross annual energy production based on a variety of factors, including efficiency and availability of the collection system, environmental factors such as blade icing and soiling, and turbine maintenance. Losses are estimated at $10 \%$ for calculated energy used in the Policy Tool.

\footnotetext{
${ }^{70}$ Cory, K., Couture, T., Kreycik, C. Feed-in Tariff Policy: Design, Implementation, and RPS Policy Interactions. National Renewable Energy Laboratory, March 2009.

${ }^{71}$ Freeing the Grid 2010. www.newenergychoices.org/uploads/FreeingTheGrid2010.pdf

${ }^{72}$ Orrell, AC. 2007. Financial Jargon for New Entrants. Poster for American Wind Energy Association WINDPOWER 2007 Conference \& Exhibition.

73 www.dsireusa.org/glossary

${ }^{74}$ Freeing the Grid 2010. www.newenergychoices.org/uploads/FreeingTheGrid2010.pdf
} 
Modified Accelerated Cost-Recovery System (MACRS): An accelerated depreciation schedule that allows businesses to recover investments in certain property on their financial balance sheets over a shorter period of time than other real assets. For solar, wind, and geothermal property placed in service after 1986, the current MACRS property class is 5 years.

Nameplate rating: The maximum output rating of a wind generator. A wind turbine that has a $10-\mathrm{kW}$ nameplate capacity will produce $10 \mathrm{~kW}$ of power when operating at its rated output.

Net meter: Net metering programs allow utility customers to generate their own electricity from renewable resources, such as small wind turbines and solar electric systems. The customers send excess electricity back to the utility when their wind system, for example, produces more power than they need. ${ }^{75}$

Net Present Value (NPV): An analysis method that takes the forecasted cash flows of a project and converts them to a present day dollar value using the project's discount rate. A positive NPV indicates that the project should be profitable, given the assumptions of the pro forma. ${ }^{76}$

Non-taxed: For purposes of this project, refers to a project owned by a government or non-profit entity that does not pay federal taxes. Wind turbines installed by the non-taxed sector cover a wide range of sizes; the Policy Tool default selection is $50 \mathrm{~kW}$.

Operations and maintenance $(\mathrm{O \& M})$ : Routine service required to keep a wind turbine running. The Policy Tool's default assumed annual O\&M cost is calculated as $\$ 0.015 / \mathrm{kWh}$.

Payback (period): The number of years required to break even on an investment. The simple payback period calculation does not account for the time value of money. ${ }^{77}$

Performance-based incentive (PBI): Provides the owner of qualifying equipment with payments based on the amount of electricity that is generated. By focusing on the energy produced instead of capital invested, the type of incentive encourages project performance. ${ }^{78}$

Permits required: Most permits issued by local jurisdictions for wind energy conversion systems are conditional use permits. Often the permitting authority will establish threshold requirements, as seen with the ordinances in Windustry's County Wind Ordinance Survey. ${ }^{79}$

\footnotetext{
${ }^{75}$ Freeing the Grid 2010. www.newenergychoices.org/uploads/FreeingTheGrid2010.pdf

${ }^{76}$ Orrell, AC. 2007. Financial Jargon for New Entrants. Poster for American Wind Energy Association WINDPOWER 2007 Conference \& Exhibition.

77 www.investopedia.com

78 www.dsireusa.org/glossary

79 www.windustry.org/county-wind-ordinance-survey
} 
Power curve: Instantaneous power output of a specific turbine design at various wind speeds; used with wind resource data to determine the potential for electricity generation at a project site. $^{80}$

Pro forma: A financial analysis prepared with a set of assumptions.

Renewable Energy Credits (RECs): The "green" or renewable attribute of electricity that is generated utilizing a renewable energy resource. Typically, $1 \mathrm{MWh}$ of wind-generated electricity produces one REC, which, in some electricity markets, can be sold separately from the electrical energy. ${ }^{81}$

Renewable Portfolio Standard/Renewable Electricity Standard: A requirement that utilities use renewable energy or renewable energy credits (RECs) to account for a certain percentage of their retail electricity sales - or a certain amount of generating capacity - according to a specified schedule. The term "set-aside" or "carve-out" refers to a provision within an RPS that requires utilities to use a specific renewable resource (usually solar energy) to account for a certain percentage of their retail electricity sales (or a certain amount of generating capacity) according to a set schedule. ${ }^{82}$

Residential: For purposes of this project, refers to a project owned by a non-commercial, individual tax payer, typically at a home or farm. Wind turbines in the residential sector are typically less than $20 \mathrm{~kW}$ but sometimes as much as $35 \mathrm{~kW}$; the Policy Tool default selections are $2.4 \mathrm{~kW}$ and $10 \mathrm{~kW}$.

Sector: Sectors are subsets of utility customers differentiated by the type of activity taking place at their facility (i.e., residential, commercial, or non-taxed entities). Some incentives restrict eligibility to certain sectors.

Setback: A term used in siting and permitting for structure installations that refers to the distance from the base of the structure to existing easements, roads, buildings, bodies of water, or other geographic or man-made structures or property lines. Setbacks for wind projects refer to permitting regulations for the distance from turbines to the aforementioned objects. A county may impose setbacks for a variety of reasons, and the requirements may vary depending on the specific land uses.

Tariff: A standardized set of terms for generation, purchase, transmission, and/or delivery of electricity on a utility's system to a state, region, or country. Commonly used in electric utility rate-making in North America and Europe. In this context, tariffs are not taxes or customs duties on goods crossing international borders.

Turbine: A device for converting the flow of a fluid (air, steam, water, or hot gases) into mechanical motion that can be utilized to produce electricity.

Wind power class: A way of quantifying on a scale the strength of the wind at a project site. The Department of Energy's National Renewable Energy Laboratory defines the wind resource

\footnotetext{
${ }^{80}$ www.wind-works.org/articles/PowerCurves.html

81 www.epa.gov/greenpower/gpmarket/rec.htm

82 www.dsireusa.org/glossary/
} 
class at a site on a scale from Class 1 to 7 ( 1 being low and 7 being high) based on average wind speed and power density to offer guidance to potential developers as to where wind projects might be feasible. Table 11 shows wind speeds in each of the wind power classes.

Table 14 Average Wind Speed by Wind Class, Based on 0.18 Shear Factor

\begin{tabular}{|c|c|c|c|c|c|}
\hline $\begin{array}{l}\text { Wind } \\
\text { Power } \\
\text { Class }\end{array}$ & $20 \mathrm{~m}(66 \mathrm{ft})$ & $30 \mathrm{~m}(98 \mathrm{ft})$ & $40 \mathrm{~m}(131 \mathrm{ft})$ & $50 \mathrm{~m}(164 \mathrm{ft})$ & $80 \mathrm{~m}(262 \mathrm{ft})$ \\
\hline $\begin{array}{c}\text { Low Class } \\
2\end{array}$ & $\begin{array}{c}4.7 \mathrm{~m} / \mathrm{s} \\
(10.5 \mathrm{mph})\end{array}$ & $\begin{array}{c}5.1 \mathrm{~m} / \mathrm{s} \\
(11.4 \mathrm{mph})\end{array}$ & $\begin{array}{c}5.4 \mathrm{~m} / \mathrm{s} \\
(12.1 \mathrm{mph})\end{array}$ & $\begin{array}{c}5.6 \mathrm{~m} / \mathrm{s} \\
(12.5 \mathrm{mph})\end{array}$ & $\begin{array}{c}6.1 \mathrm{~m} / \mathrm{s} \\
(13.6 \mathrm{mph})\end{array}$ \\
\hline Mid Class 2 & $\begin{array}{c}5.1 \mathrm{~m} / \mathrm{s} \\
(11.4 \mathrm{mph})\end{array}$ & $\begin{array}{c}5.5 \mathrm{~m} / \mathrm{s} \\
(12.3 \mathrm{mph})\end{array}$ & $\begin{array}{c}5.8 \mathrm{~m} / \mathrm{s} \\
(13.0 \mathrm{mph})\end{array}$ & $\begin{array}{c}6.0 \mathrm{~m} / \mathrm{s} \\
(13.4 \mathrm{mph})\end{array}$ & $\begin{array}{c}6.5 \mathrm{~m} / \mathrm{s} \\
(14.5 \mathrm{mph})\end{array}$ \\
\hline $\begin{array}{c}\text { Low Class } \\
3\end{array}$ & $\begin{array}{c}5.4 \mathrm{~m} / \mathrm{s} \\
(12.1 \mathrm{mph})\end{array}$ & $\begin{array}{c}5.8 \mathrm{~m} / \mathrm{s} \\
(13.0 \mathrm{mph})\end{array}$ & $\begin{array}{c}6.1 \mathrm{~m} / \mathrm{s} \\
(13.6 \mathrm{mph})\end{array}$ & $\begin{array}{c}6.4 \mathrm{~m} / \mathrm{s} \\
(14.3 \mathrm{mph})\end{array}$ & $\begin{array}{c}7.0 \mathrm{~m} / \mathrm{s} \\
(15.7 \mathrm{mph})\end{array}$ \\
\hline Mid Class 3 & $\begin{array}{c}5.7 \mathrm{~m} / \mathrm{s} \\
(12.8 \mathrm{mph})\end{array}$ & $\begin{array}{c}6.1 \mathrm{~m} / \mathrm{s} \\
(13.6 \mathrm{mph})\end{array}$ & $\begin{array}{c}6.4 \mathrm{~m} / \mathrm{s} \\
(14.3 \mathrm{mph})\end{array}$ & $\begin{array}{c}6.7 \mathrm{~m} / \mathrm{s} \\
(15.0 \mathrm{mph})\end{array}$ & $\begin{array}{c}7.3 \mathrm{~m} / \mathrm{s} \\
(16.3 \mathrm{mph})\end{array}$ \\
\hline $\begin{array}{c}\text { Low Class } \\
4\end{array}$ & $\begin{array}{c}5.9 \mathrm{~m} / \mathrm{s} \\
(13.2 \mathrm{mph})\end{array}$ & $\begin{array}{c}6.4 \mathrm{~m} / \mathrm{s} \\
(14.3 \mathrm{mph})\end{array}$ & $\begin{array}{c}6.7 \mathrm{~m} / \mathrm{s} \\
(15.0 \mathrm{mph})\end{array}$ & $\begin{array}{c}7.0 \mathrm{~m} / \mathrm{s} \\
(15.7 \mathrm{mph})\end{array}$ & $\begin{array}{c}7.6 \mathrm{~m} / \mathrm{s} \\
(17.0 \mathrm{mph})\end{array}$ \\
\hline
\end{tabular}

NOTE: 0.18 shear factor is specified in IEC 61400-2 ed. 3 and is typical for areas with low surface roughness (minimal impacts from terrain and obstructions); actual sites vary from 0.1 0.6 , and project advisers have suggested 0.3 may be more representative for distributed wind sites. A higher wind shear factor assumption would lower the estimated wind speeds at hub heights and thus annual energy production, particularly for shorter towers.

Wind shear: A term and calculation used to describe how wind speed increases with height above the surface of the earth. The degree of wind shear is a factor of the complexity of the terrain as well as the actual heights measured. Wind shear increases as friction between the wind and the ground becomes greater. Wind shear is not a measure of the wind speed at a site.

Zoning: Similar to other land uses, a county may choose to identify zones or regions within the county in which wind energy conversion systems are allowed. Generally, commercial-scale wind turbines need to be sited in locations that provide access to a good quality wind resource, which are typically found in open areas away from buildings or other obstructions. 


\section{Intended Audience}

The Web-based Distributed Wind Policy Comparison Tool and accompanying guidebook are designed to help policymakers, utilities, and advocates advance the market for on-site wind generation across the nation. Expected users include:

- Government and utility incentive program managers

- State agency wind program contacts

- Utility commission, legislative, and Congressional staff

- County planners; local utility directors and staff

- Academics and graduate students

- Think-tank and trade organizations

- Others interested in understanding distributed wind policy options.

The project is focused on addressing key market challenges and helping to ensure public dollars supporting small wind technology are spent wisely, allowing distributed wind to play an important role in reaching DOE's $20 \%$ wind by 2030 scenario and our energy future.

\section{For More Information}

\section{Database of State Incentives for Renewables and Efficiency www.dsireusa.org}

Provides information on tax incentives, rebate programs, and other state-level policies that encourage renewable energy and energy efficiency.

\section{National Wind Technology Center} www.nrel.gov/wind/

The U.S. Department of Energy's wind power research facility.

\section{American Wind Energy Association} (AWEA)

\section{www.awea.org}

A national trade association promoting the development of wind power.

\section{Distributed Wind Energy Association www.distributedwind.org}

A national trade association promoting the development of distributed wind power.

\section{Clean Energy States Alliance www.cleanenergystates.org}

A national nonprofit organization representing state-based public clean energy funds.

\section{Small Wind Certification Council www.smallwindcertification.org}

An independent certification body certifying small wind turbines that meet or exceed the requirements of the AWEA Small Wind Turbine Performance and Safety Standard.

\section{Wind Powering America} www.windpoweringamerica.gov The U.S. Department of Energy's program to dramatically increase the use of wind power across the country.

\section{U.S. Department of Energy www.energy.gov}

Provides information on federal energy program 